\title{
The New Testament kúpıos problem and how the Old Testament speeches can help solve it
}

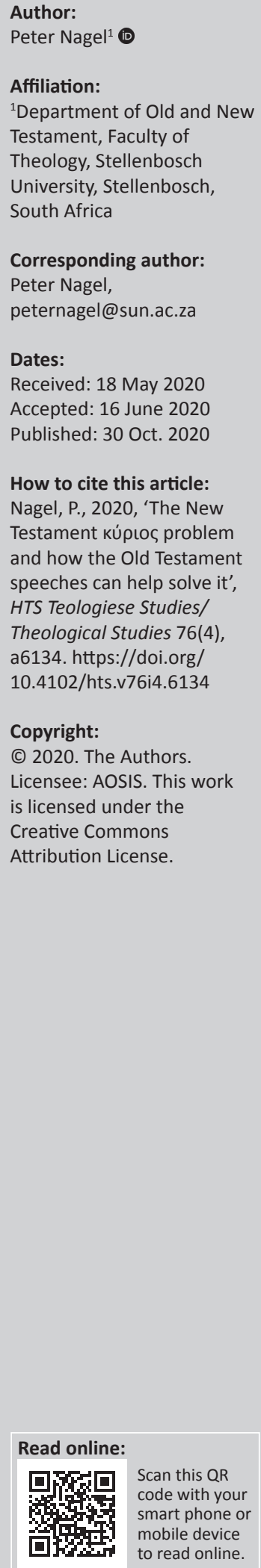

The New Testament (NT) kúpıs problem forms part of a larger interconnected network of challenges, which has the divine name Yhwh as the epicentre. To put it plainly, if the term кúpros is an equivalent for the divine name Yhwh and if the term кúpros in the Yhwh sense is applied to Jesus, the implication is that Jesus is put on par with Yhwh. This problem therefore, forms part of a matrix of interconnected issues in a constant push and pull relation. There is no easy way to address this problem, but one must start somewhere. This study will attempt to introduce, illustrate and explain the complexity of the NT кúpıs problem to contribute to a deeper understanding of the problem and to appreciate its intricacies. The aim is therefore to illustrate the intricacy of the problem by showing where the NT кúpıs problem might have originated and how it evolved. These intricacies will then be pulled into a singular focus made possible by the explicit kúpı Davidic and Jesus speeches and analysed in an attempt to contribute to a possible solution.

Contribution: This article fits in well with the contestation of 'historical thought' and 'source interpretation'. It deals with significant religious expressions found in the Hebrew Scriptures (in both the Hebrew and Greek vernacular). It not only interprets these sources, but it also aims to show the history of how these expressions were interpreted, thus, contributing to interdisciplinary discourses.

Keywords: Kyrios; Yhwh; Yahweh; YHWH; Kyrios citations; Name of a Hebrew deity; Divinity of Jesus.

\section{Introduction}

The translation of the Hebrew Scriptures into Greek was one of the biggest undertakings of its kind. It would have been impossible to accomplish such a mammoth task without some of the best minds the ancient Mediterranean society had to offer. They had to be competent on so many levels, skilled in various disciplines and had to have the ability to solve problems. But nothing could have prepared them for the translation of the divine name of a Hebrew deity; the most sacred linguistic characters the Hebrew language ever produced, יהוה (the Tetragrammaton). Translating such a significant and religious sensitive Hebrew term turned out to be one of the biggest obstacles they faced because translating this term, by definition, is a sacrilege act. To be sure, the translation of the Tetragrammaton by default implied that the divine name is stripped of its sacred status. In fact, the mere idea to translate the divine name must have been regarded as preposterous. If this did not cause translation fever amongst the scribes, then the prohibition to utter the divine name, presumably from the third century BCE onwards, must have caused some sleepless nights. To add to this, the copying of the Hebrew Scriptures during this period produced multiple Hebrew terms and scribal practises to avoid uttering the divine name. All things considered, the translation of the Hebrew Scriptures into Greek demanded nerves of steel and all the beer Alexandria had to offer.

The New Testament (NT) kúpıs problem is therefore not an isolated issue. It forms part of a much larger interconnected network of challenges, which has the divine name, יהוה (hereafter transcribed Yhwh) as the epicentre. The NT kúplos problem is pertinent for the NT and fundamental for its theology and Christology. To put it plainly, if the term kópros is an equivalent for the divine name Yhwh; and if the term kóplos in the Yhwh sense is applied to Jesus, the implication is that Jesus is put on par with Yhwh. If translating the term Yhwh was a preposterous idea, equating Jesus with Yhwh is nothing short of blasphemy; punishable by death. To reiterate, the кúpios problem is not confined to the NT, it forms part of a matrix of interconnected issues in a constant push and pull relation. There is no easy way to address this problem, but one must 
start somewhere. This study will attempt to introduce, illustrate and explain the complexity of the NT кúpıs problem to contribute to a deeper understanding of the problem and to appreciate its intricacies. The aim is therefore to illustrate the intricacy of the problem by showing where the NT kúpros problem might have originated and how it evolved. These intricacies will then be pulled into a singular focus made possible by the explicit kúpıs citations. These citations, in turn, will be categorised as Theos', David's and Jesus' speeches and analysed in an attempt to contribute to a possible solution.

\section{Defining the problem}

A question that petitions to be answered is whether a kúpros problem is not just an illusion. Is the so-called кúpıs problem not theresultofaculturaldisconnection and misunderstanding of ancient texts, concepts and social contexts? Is this not a case of postulating a problem onto ancient Hebrew and Greek texts because of sociocultural and religious estrangement? The manuscript evidence, however, will reveal that a kv́pı reality. The NT кúpıs problem is both conceptual and linguistical in nature; conceptually, it is a matter of who Jesus was perceived to be predominately in relation to a Hebrew deity, and albeit to a lesser extent, the Emperor as dominus. Linguistically speaking, it is a culmination brought about by the complexities of all the Hebrew and Aramaic terms used to reference a Hebrew deity and finding a suitable Greek equivalent in translating these terms. ${ }^{1} \mathrm{~A}$ few assumptions are made that form the basis for the NT кúpıos problem:

1. a prohibition was in place from the third century BCE onwards prohibiting the pronunciation of the name for the Hebrew deity, Yhwh (cf. Tov 2020:49)

2. the rule of thumb is that the term kópros is a suitable Greek equivalent for the Hebrew term

3. the term kúpro $̧$ in the sense of Yhwh, as a divine name, is not applied to Jesus, irrespective of its ambiguity. ${ }^{3}$

These assumptions are problematic for primarily three reasons; firstly, there is no manuscript evidence of an uncontracted אúplos term as an equivalent representation of יהוה from the third century BCE to second century CE. Certainly, the evidence only

\footnotetext{
1.Tov (2020:47-58) is of the view that kúploc is a standard equivalent for יהוה, which is a straightforward linguistic equation кúpı $=$ = (יהוה) = אדני (2), 48, Tov, also puts forward (is a counter scenario, suggesting that Masoretic Qere perpetum is a later Hebrew retroversion of the LXX equivalent הוn, kuplos. According to this version, this equivalent is not a straightorward linguistical one, but 'involves the theological rendering of the name of the God of Israel with a Greek noun designating the "master of the Universe,"' p. 49; cf. Bousset (1970:129).

2.Baudissen (2016:11-12), suggested in the light of the Hexapla and in particular Aquila and Theodotion, that the term kúploৎ was the preferred term.

3.Cf. Bousset (1970:125-128), like many others, acknowledged the complexity surrounding the use of the term kúplos as a title for Jesus. He wrote that the introduction and extensive use of the title without a first personal pronoun as attested in the Pauline literature marked a rapid development in Christianity; a development which saw that the absolute ó kúpioç is ascribed to Jesus, a designation reserved for the 'exalted One' and not the historical Jesus. He goes on to say the expectation was, within Hebraic Judaism at least, to use the term kúpı so for a expectation was, within Hebraic Judaism at least, to use the term kúplos for a
Hebrew deity who is 'Kyrios of the kings' and 'Kyrios of heaven'. This implies that the significant transition from the divine name 'Jahve' to the divine name 'Lord' did not take place in the region of Hebraic Judaism but is rather a peculiarity of Jewish take place in the region of Hebraic Judaism but is rather a peculiarity of Jewish
Hellenism. Therefore, the use of ó kúploc for Jesus in the religious sense, is only conceivable on the soil of Hellenistic, p. 128.
}

reveals an abbreviated form of the term kóplos, a practise known as the nomina sacra. ${ }^{4}$ Secondly, there are numerous manuscript evidence suggesting alternatives to the nomina sacra as Greek equivalents for Yhwh. Thirdly, it is difficult to determine whether the term кúpios applied to Jesus was understood to be in the 'Yhwh' sense of the word. These 'so-called' Jesus-Yhwh equated occurrences are riddled with ambiguity, to say the least. Two theories will be put to test in this regard: (1) whether the term אúpıo̧ as an equivalent for יהוה is a theological rendering designating 'master of the universe,' (cf. Baudissen 2016:128; Tov 2020:49) and (2) if the articulated kúptos, the absolute form is understood to be Yhwh and ascribed to Jesus. As was stated before, the issue is a complex one; it forms part of an interconnected web of textual problems.

\section{An interconnected web of textual problems}

The history leading up to the formation of the Jesus movement and the production of written material relating to Jesus as the central figure of this movement, reveals an intriguing web of interconnected issues all contributing to what is referred to here as the NT kópios problem. What the study wants to convey with this idea of an interconnected web is that no issue, irrespective of when it occurred in history or where and how it is situated in the process (conceptualisation, transmission and translation), ever reach a static state; they remain fluid and ever-evolving. Think of it as a circular web with lines cutting across; forming nodes (connections) where they cut across the circular lines. These nodes represent a кúpıs problem and when you address a certain problem (pushing and pulling the node), the entire web is impacted. The nodes closest to the one being pushed and pulled will be affected the most. Here are some of these nodes, of which only a few will be discussed in detail:

1. a Hebraic concept of Yhwh

2. transmission of the term in the Hebrew tradition

3. the translation of the term into Greek

4. transmission of the term in the Greek tradition

5. a Hellenistic/Graeco-Roman concept of the term кúpıs

6. the theology and kyriology of the NT; using the term кúpı̧ for Jesus.

\section{A Hebraic concept of Yhwh ${ }^{5}$}

It is beyond the scope of this study to responsibly deal with the term יהוה as it is conceptualised in the Hebrew Scripture.

4 A practice whereby important religious and significant terms a a o abbreviated. Hurtado (2006:96), writes that 'the nomina sacra are so familiar a feature of Christian Hurtado (2006:96), writes that the nomina sacra are so familiar a feature of Christian
manuscripts that papyrologists often take the presence of these forms as sufficient to manuscripts that papyrologists often take the presence of these forms as sufficient to
identify a fragment of a manuscript as indicating its probable Christian provenance;' Heath (2010:517), states that the nomina sacra are the frequent abbreviations of certain words in early Christian manuscripts. Tuckett (2003:431-458), suggested that $\mathfrak{P P}^{52}$ (P. Rylands Gk [Greek papyri] 457), considered as one of the oldest text fragments of the NT, did not have the distinctive Christian abbreviations. He claimed that it may have significant ramifications upon widely held views about this scribal practise. This was later successfully rebutted by Hurtado (2003:1-14).

5.Rösel (2007:411-428), aptly responded to the problem whether the Masoretes

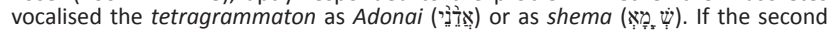
assumption is correct, reading 'Lord' is to be regarded as a later tradition, 411 . He is aware of the complexity when he observes that the tetragrammaton is vocalised as Elohim when used with , 412 . He also notes that the holem-dot is not written although Elohim should be read, after which he concludes that qere of not שִ. p. 413. Van Bekkum (2006:3-15), wrote that creation and name (either by not w. W, p. 413 . Van Bekkum (2006:3-15), wrote that creation and name (either by
the power of the name of God or by combining letters to names) were considered as parts of formative processes by which God succeeded to bring the world and its 
What can be said at this point is that the Hebrew concept of a deity, within its ancient near Eastern context, ${ }^{6}$ was not as homogeneous as often suggested. ${ }^{7}$ The evidence suggests a more differentiated and nuanced picture of how a Hebrew deity was conceptualised. The Hebrew Scriptures demonstrate different phases of how ancient Israel's religion developed, characterised by polytheism, monotheism and henotheism, none of which reached a static state. ${ }^{8}$ These phases of development testify to variations, differentiations, fluctuations, and inconsistencies. ${ }^{9}$ The different nuances in how ancient Israel perceived a deity, particularly their deity, to be and how they called upon such a deity, is under appreciated. For example, an $E l$ as a significant element of Elohim named and referred to as El Shaddai ${ }^{10}$ and Yhwh, both being a type of $E l$. The concept of a primordial deity $(E l)$ and Yhwh becoming the significant $E l$ for the Hebrew people augments the complexity factor. In other words, $E l$ is the primordial substance of what constitutes an Elohim, in some instances referred to as El Shaddai; while Yhwh is a type of El that became the Elohim of ancient Israel. ${ }^{11}$ The variety and potential scope of deity concepts offered by the Hebrew text contributed significantly to transmission of these concepts in the Hebrew tradition. This is not to suggest that Yhwh is not pivotal and central for ancient Israel religion, but a conceptual variation of a Hebrew deity should be considered as a possibility. The transmission of the term יהוה seems to support such.

\section{Transmission of the Yhwh term in the Hebrew tradition}

The destruction of the temple in 587 BCE had a devastating impact on ancient Israel, ${ }^{12}$ but the subsequent edict of Cyrus, king of Persia, in 539 BCE, which saw the elite return to the province of Yehud created renewed hope to restore and rebuild the temple and the city that cradled it, namely Jerusalem. The ambition of king Philip II of Macedonia, would in due course shatter this renewed hope as illustrated by the brutal war for Judean religious identity and independence, which came to be known as the Maccabean revolt during the second century BCE. ${ }^{13}$ Philip II's son,

\footnotetext{
creatures into being. He then goes on to write that paying respect to God's name in the cultic sense defines the relationship between God and Israel, p. 4.
}

6.See the chapters 'Fluidity of Divine Embodiment and Selfhood: Mesopotamia and Canaan' and 'The Fluidity Model in Ancient Israel' in the monograph of Sommer (2009).

7.See the very recent publication of Shechter (2018:6). Here Shechter states that YHWH is the standard name for the God of Monotheism and that this standard name harbours the authentic connotations of the monotheistic doctrine in Hebrew scripture. Also see Collins (1997) and Gnuse (1997:392)

8. Lynch (2014a:1), pointed out that there are two perspectives in scholarship regarding the development within monotheism; the one is moving away from an institutional expression of Yahwism to a more universal form thereof and the other is that even before the exile monotheism became inseparable and problematically wedded to particular institutions of authority like the monarchy and priesthood and post-exilic period merely continued along these lines.

9.Lynch (2014b:47-68), remarked that the range of texts and rhetorical modes inhabit Israel's monotheistic landscape. He then goes on to ask what the implications of biblical variation in monotheistic rhetoric are.

10.Tov (2020:53), noted that this divine name was not recognised by the translators of the Pentateuch, but it was in the later books. In most cases, according to him, שדי was rendered as a prenominal suffix in rabbinic Hebrew as 'my', kingdoms.

11.Gericke (2017), extensively deals with El as a category, amongst others.

12.See Grabbe (2010:2), for a brief overview of the 586 events.

13.Jonker (2016:65), hypothesises that process of identity negotiation already took place during the Persian period because of four levels of sociohistorical existence
Alexander III of Macadeon, ${ }^{14}$ took over the reins after he (Philip II) was assassinated in 336 BCE. Alexander was subsequently awarded generalship of Greece and used this authority to embark on an unprecedented military campaign through Asia and northeast Africa where he created one of the largest empires of the ancient world. This saw his father's Panhellenic project to lead the Greeks in the conquest of Persia come to fruition. After the sudden death of Alexander in 323 BCE, his kingdom was divided amongst his generals who fought for control over the empire. This infighting caused the empire to be divided into several different kingdoms. ${ }^{15}$ The political uncertainty, among other factors, were the impetus for different religious sects to form and for 'the Hebrew people' to reevaluate their religious and political identity as affirmed and shaped by the Hebrew Scriptures, or more specific, the Torah. ${ }^{16}$ A need arose to preserve the Hebrew Scriptures by making various copies presumably from the third century BCE onwards. It is postulated that during the same period, ${ }^{17}$ pronouncing the 'sacred name' of the Hebrew deity, Yhwh, was prohibited. The manuscript evidence seems to support these postulations; they attest to manifold possibilities in rendering 'the name' as demonstrated by the manuscript extracts from Qumran of which the 'Community Role' (1QS) will be referenced first. ${ }^{18}$

\section{Sectarian manuscripts}

IQS (community role) ${ }^{19}$ : In Figure 1 , line 14 it is shaded where the scribe uses four dots when referring to Yhwh. He writes that whilst Israel was in the desert (indicative of the

which prompted different power relations; cf. Johnson (2010:64). Gerstenberger (2005:355), points out that the notion that Yhwh is considered to be the (my personal emphasis) deity who made a pack with the Israelites, and by so doing wanted all other nations under is ruled started fading during the last three decades. The idea of Yhwh being the 'almighty' one had its origins in the fluctuating history of ancient Israel. Monotheism had its roots in the new constitution of the faith community during the Persian period.

14.Commonly referred to as Alexander the Great.

15. Most notably, the kingdom of Ptolemy | Soter, Cassander, Lysimachus and 5.Most notably, the kingdom of Ptolemy Soter, Cassander, Lysimachus and Seleucus Nicator. Significant for the purposes here are the kingdoms of Seleucus, who reigned over Palestine, Asia Minor and further west. Johnson Seleucus, who reigned over Palestine, Asia Minor and further west. Johnson
(2010:64), emphasised that Palestine was never a secure imperial possession. The political strive inferred from the period of the Maccabean revolt to the collapse of messianic hope after the Bar Kochba rebellion contributed to the division in and around Palestine.

16.Goodblatt (2006:29-30), observed that the Hebrew Scriptures provided a 'national history' and shared culture of ancient Israel; the stories about the patriarchs and the tribal eponyms in the Pentateuch established the shared physical ancestry of all Israelites. The distinctive cultural markers of Jewish identity included circumcision of male infants, avoidance of pork, observance of the Sabbath and circumcision of male infants, avoidance of pork, observance of the Sabbath and
endogamy. Collins (2012:455-474), pointed to the centrality of the Torah in late Second Temple Judaism. So, when Antiochus Epiphanes tried to impose syncretistic worship by placing the statue of Zeus Olympus in the temple and forbiddin observance of Torah (1 Macc [Maccabees] 1:41-57; 2 Macc 6:1-11), it obviously struck a religious zealous nerve, which resulted in what is now referred to as the Maccabean revolt.

17.In the so-called temple scroll (CD) a Hebrew deity is referenced by predominantly using the term לא; cf. CD 1.2, 10; 2.1, 3, 7, 15, 18; 3.2, 4, 6, 8, 11-13, 18, 21; 4.7, etc. This is also true for the community role (1QS); cf. 1QS 1.7, 8, 10-14, etc., except for 1QS 8.13 and 8.14 .

18.The manuscript extracts were 'screen grabbed' from the Leon Levy Dead Sea Scrolls Digital Library, viewed 30 March 2020, from https://www.deadseascrolls.org.il/ home as well as the digital manuscripts offered by the Israel Museum, viewed 31 March 2020, from http://dss.collections.imj.org.il/.

19.The Community Rule (Serekh Hayahad, 1QS), formerly called the 'Manual of Discipline,' is the major section of one of the first seven scrolls discovered in Cave 1 at Qumran in 1947. Written in Hebrew in a square Hasmonean script, it was 1 at Qumran in 1947 . Written in Hebrew in a square Hasmonean script, it was
copied between 100 and 75 BCE, see The Digital Dead Sea Scrolls, viewed 31 March 2020, from http://dss.collections.imj.org.il/community. 


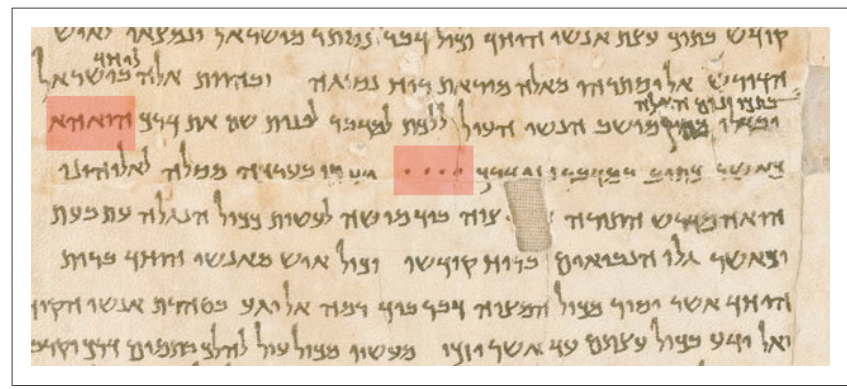

Source: The Digital Dead Sea Scrolls, n.d., 'The Community Rule', viewed 31 March 2020, from http://dss.collections.imj.org.il/community

FIGURE 1: 1QS, line 11-18 (Community Role).

second person pronoun 'you' in line 12) they abandoned the way of 'Yhwh' (shaded in Figure 1, line 13), followed by an Isaiah 40:3 quotation in line 14. The use of four $\operatorname{dots}^{20}$ (1QS 8.14) for the reproduction of Yhwh is not repeated elsewhere in the community role, ${ }^{21}$ and the use of the term in line 13 as a a rendition for Yhwh is a hapaxlegomina. ${ }^{22}$ In fact, the use of the four dots to reproduce a Hebrew deity is not common among texts found in the Judean desert. The so-called 'War Scroll' (1QM) makes no reference to a Hebrew deity using any equivalent term for Yhwh. What is a unique characteristic in $1 \mathrm{QM}$ is the dominant use of 2 in referencing a Hebrew deity. ${ }^{23}$ The scribal practice used to reproduce Yhwh appears to be somewhat different in the temple scroll (11Q19).

11Q10 (temple scroll) ${ }^{24}$ : In Figure 2, the name of the Hebrew deity, Yhwh, is rendered using square Hebrew script as can be seen in lines 13 and $14 .{ }^{25}$ This scribal practise dominates this manuscript; as a matter of fact, it dominates most of the documents found in the Judean desert. ${ }^{26}$ Tov (2004:207) listed a dicolon (:) used throughout $4 \mathrm{QRP}^{\mathrm{b}}(4 \mathrm{Q} 364)$ and the uncommon and uncertain use of different colours of ink for in 11QpalaeoUnidentified Text (11Q22) (Tov 2004:207). He concludes that the four types of special writing systems

20.Stegemann (1969:152), named this Tetraouncta. According to Tov (2004), the fou dots in texts written in the square script represent the Tetragrammaton in eight nonbiblical and biblical texts written in the Qumran scribal practise, as well as in

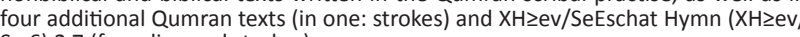
Se 6) 27 (four diagonal strokes).

21.This includes the fragments of at least 10 additional copies (4Q255-264 and 5Q11) There is a reference to ואדו in 1OSb 5.8, but because of its fragmentary nature the literary context is difficult to reconstruct. Seven other texts also attest to the four

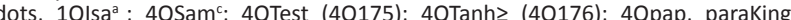
(4Q382); 4QNarrative C (4Q462); $4 \mathrm{QT}^{\mathrm{b}}$ (4Q524); not written in the Qumran scriba practice: four strokes in 4QMen of People (4Q306); 4QpapToba (4Q196); 4QHistorical A (4Q248); 4Qpap psEzek (4Q391); cf. Tov (2004:206).

22.The reconstruction of $4 Q 2586.7$ also reads הואהא but it was obviously reconstructed as such based on 1 QS 8.14.

23.1QM 10:4, 7; 18:4 are the exceptions; cf. Tov (2004:224-225). He states that in some instances the Tetragrammaton was replaced by 2 (e.g. 4QpPs $; 4 \mathrm{QHos}^{\mathrm{b}}$; in $1 \mathrm{QH}^{\mathrm{a}}$ vi (יהוה replaces. He further states that the preponderance of אדוני writings (pesharim, Hodayot, prayers, blessings, Rules) as opposed to the rare use of the Tetragrammaton in these writings provide ample evidence of this avoidance, especially in $1 \mathrm{QS}$ and $1 \mathrm{QH}^{\mathrm{a}}$. Rösel (2007:413), also observed the predominance of the designation $ל$ for a Hebrew deity.

24.See The Digital Dead Sea Scrolls, viewed 31 March 2020, from http://dss. collections.imj.org.il/temple for an overview of the scroll and its characteristics.

25.Cf. $11 Q 19$ 14:0, 7, 8.

26.11019, 14:7,8; 15:13; 16:4, 5, 10; 17:12, 13, 16; 18:13, 14; 19:11; 20:0, 14; 21:3, 8, 10 $16 ; 22: 8,14,16 ; 23: 3,17 ; 24: 9 ; 25: 4,13 ; 28: 6 ; 34: 14 ; 39: 8 ; 45: 14 ; 51: 7 ; 54: 12,13 ; 55: 9$ $60: 0 ; 61: 3 ; 63: 7$ In 11Q19 48:7-10; 53:8; 54:16; 55:0, 14; 60:21; 61:0; 63:8 the manuscript produces the fixed construct ליהוה אלוהיכה. Stegemann (1969:157), suggests that the Tetrapuncta preceded the writing of the divine name in square characters.

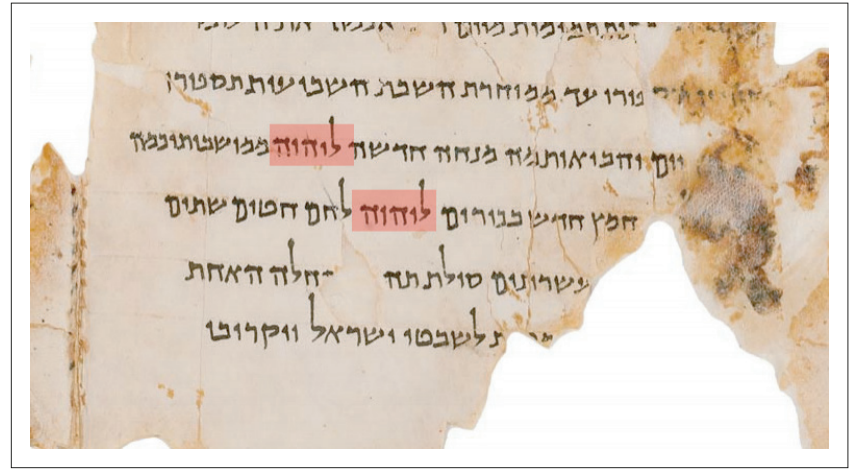

Source: The Digital Dead Sea Scrolls, n.d., 'The Temple Scroll', viewed 31 March 2020, from http://dss.collections.imj.org.il/temple

FIGURE 2: 11Q19, line 12-16 (Temple scroll).

for the divine names are closely connected to the Qumran scribal practise, and that no Hebrew texts of a non-sectarian nature or those clearly not written in the Qumran scribal practice containing any of the aforementioned scribal systems for the writing of the divine names have been preserved (Tov 2004:207-208).

A reasonable observation is that there were no standardised scribal practises adopted by scribes of the sectarian manuscripts when it came to the reproduction of the divine name, Yhwh. Reproducing the term remained a religious sensitive matter, often reflecting reverence for, and fear of, uttering the divine name. The יהוה was considered so sacred that it was not written with regular characters. ${ }^{27}$ The challenges posed by the sacred divine name, Yhwh, was certainly not limited to the sectarian or non-biblical manuscripts but proved to be equally challenging for the scribes who copied the biblical content.

\section{Biblical manuscripts}

1QpHab (Hab 2:16-20): There were a few manuscripts from the Judean desert written in square and palaeo-Hebrew script. The finds from Qumran and Masada include several forms of writing in palaeo-Hebrew characters. Tov (2004:207-208) characterised them as follows:

1. Individual letters (scribal markings)

2. Divine names

3. Texts written entirely in palaeo-Hebrew characters (Tov 2004:224).

The peculiar use of palaeo-Hebrew script ${ }^{28}$ to reproduce Yhwh was not as uncommon as one might think. According to Tov (2004:225) the writing in palaeo-Hebrew characters probably ensured the non-erasure of the divine name. ${ }^{29}$ The extract from 1QpHab (commentary on Habakkuk) in Figure 3

27.CF. Tov (2004). Rösel (2007:414), suggest that reading 'God' for the tetragrammaton was the normal custom at Qumran.

28.2QpalaeoLev; 4QpalaeoExod ${ }^{m}$; 4QpalaeoGen-Exod ${ }^{1}$; 4QpalaeoDeut'; 11QpalaeoLev ${ }^{\mathrm{a}}$ amongst others; see a complete list in Tov (2004:231-232).

29.Tov (2004:225). He provides valuable data and insight into the use of palaeo-Hebrew and square Hebrew characters in combination. See also Table 1 in Tov (2004:227-228), for a list of manuscripts where the Tetragrammaton was written in palaeo-Hebrew characters, and Table 2 where the divine name and El are written in square Characters in Texts written according to the Qumran scribal practices, Tov (2004:229-230). 


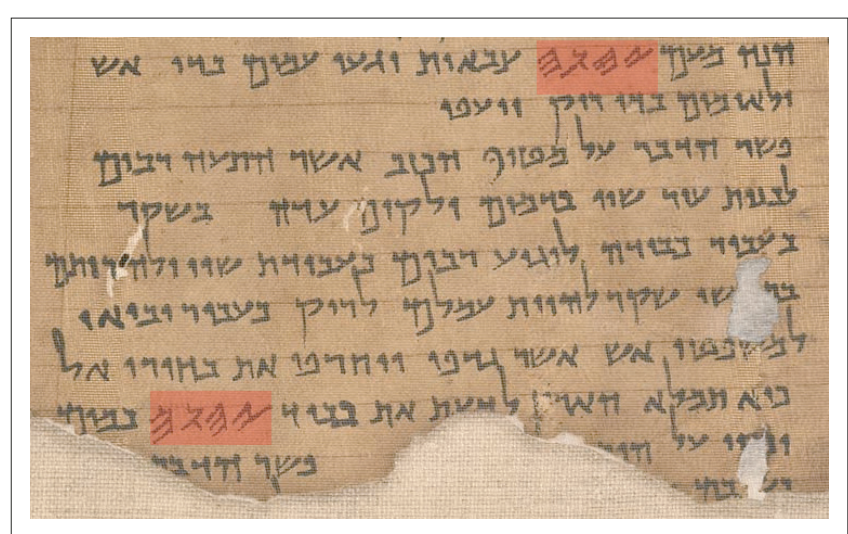

Source: The Digital Dead Sea Scrolls, n.d., 'The Commentary on Habakkuk Scroll', viewed 31 March 2020, from http://dss.collections.imj.org.il/habakkuk

FIGURE 3: 1QpHab, col. 10 (Hab 2:16-20).

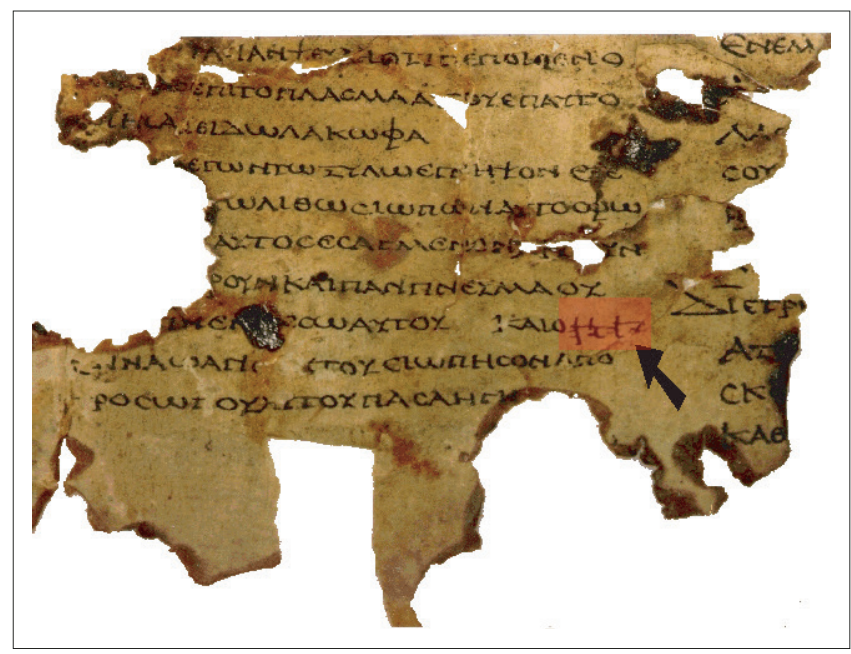

Source: The Leon Levy Dead Sea Scrolls Digital Library, n.d., 'Minor Prophets', viewed 30 March 2020 from https://www.deadseascrolls.org.il/explore-the-archive/manuscript/8Hev1-1 FIGURE 4: 8HevXIlgr, col. 18 (Hab 2:16-20).

is but one illustration. In fact, this scribal practise was not limited to manuscripts written in square Hebrew script, but also influenced manuscripts written in Greek. ${ }^{30}$ The Nahal Hever finds (manuscripts dated to 50 BCE-50 CE) consistent use of palaeo-Hebrew script without exception (see Figure 4 as illustration).

8HevXIIgr (Hab 2:16-20): Returning to the challenge faced by scribes in rendering the name of the Hebrew deity, no other manuscript illustrates the complexity more than the 'Large Isaiah Scroll’ (1QIsaa) (See Nagel 2012:173-191), Figure 5.

IQIs a (Is 3:15-18): In Figure 5, at the end of line 20 (Is 3:15), the manuscript reads Yhwh with a superscript reading Adonaj. ${ }^{31}$ In line 24 (Is 3:17) the manuscript reads Adonaj with a superscript reading Yhwh, and the direct opposite is again found in line 25 (Is 3:18) reading Yhwh with a superscript Adonaj. ${ }^{32}$ What apparently caused the confusion 30.See also $110 \mathrm{Ps}^{\mathrm{a}}$ dated to $1-68 \mathrm{CE}$, also using palaeo-Hebrew script.

31.Cf. 1 QIsa ${ }^{a}$ col. XXII, line 20 (Is 28:16); XXIV, line 25 (Is 30:15); col. LII, line 18 (Is 65:13). See also 1QIsa col. VII, line 27 (Is 8:7) attesting to blank space and Adonaj as superscript.

32.Rösel (2011:38), states that both Adon and Adonaj were used in the Old Testament primarily to designate God. He also points out that these terms were also used

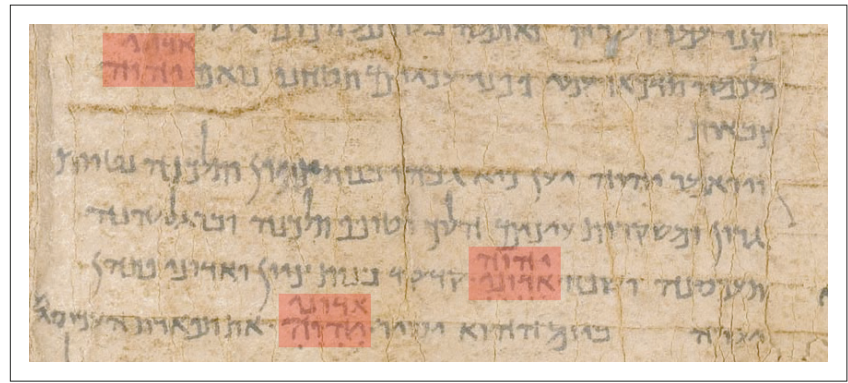

Source: The Digital Dead Sea Scrolls, n.d., 'The Great Isaiah Scroll', viewed 31 March 2020, from http://dss.collections.imj.org.il/isaiah

FIGURE 5: 1QIsa', col. 3 (Is 3:15-18).

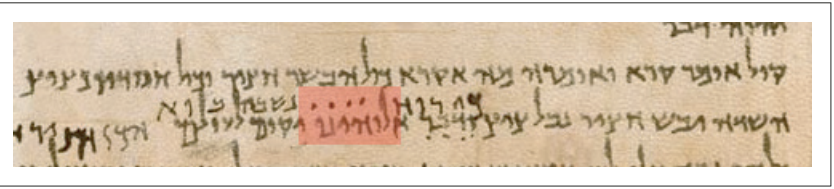

Source: The Digital Dead Sea Scrolls, n.d., 'The Great Isaiah Scroll', viewed 31 March 2020, from http://dss.collections.imj.org.il/isaiah

FIGURE 6: 1QIsaa, col. 33 (Is 40:7).

is brought about by the Qere and Ketib tradition; what ought to be written and read, respectively, which is obviously not limited to 1 QIsa ${ }^{a}$ but can be observed elsewhere (cf. Tov 2020:49).

In Figure 6, a redactor inserted four dots above Adonaj, presumably indicating that this is what ought to be read, but the term יהוה was meant.

The three manuscript extracts are only revealing the tip of the iceberg. The data from the Judean desert finds are overwhelming. An apparent inference is that like the nonbiblical manuscripts, here too there was no standardised scribal system on how one should render the 'name' of the Hebrew deity. These illustrations produce not less than five terms used to render the divine name Yhwh:

1. square Hebrew characters

2. palaeo-Hebrew characters

3. four dots

4. Adonaj

5. the term הואהא.

To confirm, these are not the only possibilities, but it sufficiently illustrates the scribal variety with the reproduction of the divine name, Yhwh. These reproductions also created fertile soil for unearthing numerous complex challenges for the Greek translators of the Hebrew Scriptures.

\section{Translating the term יהוה with a Greek 'equivalent'}

The array of possible renderings of Yhwh within the Hebrew frame of reference must have caused endless translation nightmares for the scribes responsible for translating the Hebrew Scriptures. What follows are a few illustrations revealing some of the challenges faced by the Greek

when reference is made to an authoritative 'Master', and that it is predominately used in combination with Yhwh; also see the monograph of Rösel (2000:49). 
TABLE 1: Deuteronomy 3:17-26

\begin{tabular}{|c|c|c|c|c|}
\hline \multirow[t]{2}{*}{ Reference } & \multicolumn{2}{|c|}{$4 Q 31$} & \multirow[t]{2}{*}{ Papyri 693} & \multirow[t]{2}{*}{ Codex S } \\
\hline & Deuteronomy $^{d}$ & Deuteronomy $^{m}$ & & \\
\hline Deuteronomy 3:20a & יזהוֹה ל]אחיכם] & יהוה אלוהי & o $\overline{\theta \cdot \zeta} \eta \mu \omega \nu$ & $\overline{\kappa \zeta} \circ \overline{\theta \zeta \zeta}$ \\
\hline Deuteronomy 3:20b & 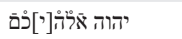 & ] אלוהכימה יהוה & $\overline{\kappa \varsigma} \circ \overline{\theta \zeta} \ddot{0} \mu \omega v$ & $\overline{\kappa \varsigma} \circ \overline{\theta \zeta} \ddot{0} \mu \omega \nu$ \\
\hline Deuteronomy 3:21a & "[הוה א]לה"היכם & Not visible & o $\overline{\theta \zeta} \eta \mu \omega \nu$ & $\overline{\kappa \varsigma} \circ \overline{\theta \zeta}$ \\
\hline Deuteronomy 3:21b & יהוה & Not visible & $\overline{\kappa \varsigma}$ & $\overline{\kappa \varsigma}$ \\
\hline Deuteronomy 3:24 & אדני יהוה & Not visible & $\overline{\kappa \varepsilon} \overline{\kappa \varepsilon}$ & $\overline{\kappa \varepsilon} \sigma \nu$ \\
\hline
\end{tabular}

Note: Deuteronomy ${ }^{d}$ and Deuteronomy ${ }^{m}$ refers to 4 QDeut ${ }^{d}$ and 4 QDeut ${ }^{m}$ respectively. The ${ }^{d}$ and ${ }^{m}$ are used to index different fragments. Manuscripts $71+619$ read $\overline{k \zeta}$ o $\bar{\theta} \varsigma$ at the first instance, whereas the first hand of Codex $B$ read o $\theta \bar{\varsigma}$ with others varying between $\bar{\kappa} \kappa \xi 30^{*}$ and $\theta \varepsilon \varepsilon 630 \mathrm{c}$

translators when an attempt was made to translate the term יהוה 33 The first illustration is Deuteronomy 3:17-26.

The inconsistency and confusion in translating יהוה particularly when used in combination with אלהים presented in Table 1 is evident. The term Yhwh is rendered in the Greek idiom using three different terms or combination of terms: o. I. o I.. and in some cases the term is not rendered at all. The Hebrew text tradition remained consistent in using the square Hebrew characters to signal Yhwh. In the case of Deuteronomy 3:24, papyri 963 renders as דני יהוה, whereas codex Sinaiticus only reads. ${ }^{34}$ It was not uncommon to

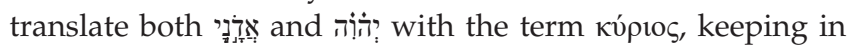
mind that in all cases the data reveal a contracted form of the term. ${ }^{35}$ Another on-point illustration is Isaiah 28:16.

\section{QIsaa (Is 28:16)}

In the case of Isaiah 28:16 (Figure 7) the text reads Yhwh in square Hebrew characters with a superscript Adonaj, which is characteristic of the 1 QIsa ${ }^{a}$ scroll as indicated earlier. In Codex Leningradensis, ${ }^{36}$ the superscript presumably found its way

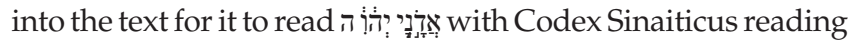
a single $\overline{\kappa \varsigma}$. The point of contention is whether the term $\overline{\kappa \varsigma}$ is an equivalent for the superscript Adonaj or Yhwh. ${ }^{37}$ The Hexapla recension $^{38}$ read an additional $\kappa v \rho ı \varsigma$, the Lukian recension ${ }^{39}$ attest to a plus reading o $\theta \varepsilon \circ \varsigma$. A similar type of issue is present in Isaiah 28:22; in 1QIsa it reads יהוה מדוזני but in the MT it reads ירנית but in this case the Greek text tradition reads. In the latter it seems as if Adonaj found its way outside of the text. Another striking case is found in Lamentations 1:14-17.

\section{QLam (4Q111), (Lm 1:14-17)}

In the short space of a few lines of text (Table 2) it is unclear which terms represent what and whom. It is uncertain

33.Tov (2020:54), offers a table of LXX Equivalents for the Divine Names in Genesis 1-11. He then comments that the major problem lies with the combination יהוה אלהים with
no standard equivalent. Both Tov (2020:48-49) and Rösel (2007:414) agree that $\theta \varepsilon$ co is the standard Greek equivalent for אלהים, and kuplos for הוה'; at least for the Pentateuch. They both acknowledge that it is not as straightforward as it seems.

34.Cf. Genesis 24:27 where Papyri 962.

35.There is an enormous amount of data showing this, but the exception to the rule is what is of interest.

36.Only the last two characters of יה in 1Qlsa ${ }^{\mathrm{b}} \mathrm{frg} 6$, col. II, is visible, so it is not possible to determine whether this manuscript had already read the two terms in-line.

37.A large amount of manuscripts $\left(O^{\prime}-\mathrm{Q}^{\mathrm{mg}} 403^{\prime} 449^{\prime}\right)$ read an additional kuplos, whereas others ( $\left.L^{\prime \prime}-233-456\right)$ attest to a plus reading o $\theta \varepsilon \circ$ s.

38.Consisting of codex Vaticanus and Venetus, amongst others indicated by the symbol $O^{\prime}$, but some within this group notably $Q^{\mathrm{mg}} 403^{\prime} 449^{\prime}$ does not read an additional kupıs term.

39. Indicated by the symbol $L^{\prime \prime}$, but not all within this group attest to the plus reading, see 233-456.

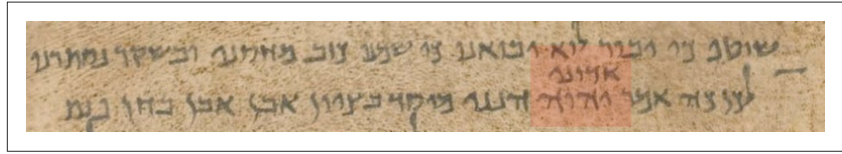

Source: The Digital Dead Sea Scrolls, n.d., 'The Great Isaiah Scroll', viewed 31 March 2020, from http://dss.collections.imj.org.il/isaiah

FIGURE 7: 1QIsaa , col. 22 (Is 28:16).

TABLE 2: Lamentations 1:14-17

\begin{tabular}{|c|c|c|c|}
\hline Reference & 4QLam & MT & Codex S \\
\hline Lamentations 1:14 & יהוֹה & אֶדלנּי & $\overline{\kappa \zeta}$ \\
\hline Lamentations 1:15 & 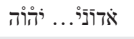 & 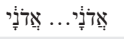 & $\overline{\kappa \zeta} \ldots \overline{\kappa \zeta}$ \\
\hline Lamentations 1:17 & איהּוֹה... אדוני & ירונה & $\overline{\kappa \zeta}$ \\
\hline
\end{tabular}

MT, Masoretic Text.

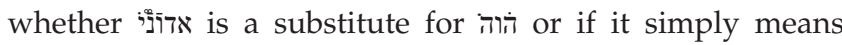
'master'. Codex S uses $\overline{\kappa \varsigma}$ throughout, avoiding duplication in Lamentations 1:17. These examples are not the exception but are so frequent that one could even define it as the rule. In summary, it is uncertain if and to what extent the term kv́pios was used to translate Yhwh. Moreover, when Yhwh was used in combination with Elohim or Adonaj, or both, the Greek text tradition in part adopted a practise of conflating it to a single term in various instances. One should therefore be cautious when postulating the idea that the term $\theta \varepsilon$ ć $\varsigma$ is a Greek equivalent for Elohim and the term kópros for Yhwh; it is far more complex and nuanced than that. ${ }^{40}$

A few postulations should be in order at this point:

1. Linguistically speaking, the term kúpıs might be an equivalent Greek term for יהוה, but semantically, conceptually it is not Yhwh; it is a phonetic representation of the divine name.

2. Kyrios is therefore not a type of $\mathrm{El}$ as Yhwh is one.

3. Kyrios is not a name of a Hebrew deity, but a term used to translate the Hebrew term יהוה.

4. Kyrios represents a quality of a Theos as appose to a type.

5. It is therefore to be expected that finding a Greek equivalent for the divine name was not an easy matter, as is evident from the Greek manuscript data.

\section{Transmission of the term kúplos in the Greek tradition}

It is somewhat artificial to draw a distinction between 'translation' and 'transmission', as if an 'original' source and target text are available. Nevertheless, the aim here is to show how the term יהוה is rendered by the oldest Greek manuscripts testifying to 'biblical' content. By becoming aware of the variant possibilities, it will reveal how it contributes to the NT кúpıs problem. These manuscripts are Papyrus Rylands 458, 4Q122 (4Q LXXDeut), 7Q1 (7Q1 LXXEx), 7Q2 (7QLXXEpJer) and 4Q121 (4QLXXNum). Unfortunately, none of them offer any data on how the term יהוה was rendered. Manuscript 4QLXXDeut, however, does present an unusual open space in

40.Two prominent voices in this debate should be mentioned. The first voice is Rösel in 'אדו ', p. 1955, Rösel (2000) and Rösel (2007). The second voice is de Troyer (2008:143-172). De Troyer is of the view that vocalisation for יהוה' was such that (2008:143-172). De Troyer is of the view that vocalisation for ' was such that
one would pronounce it Elohim, whereas Rösel holds the view that Adonaj is to be pronounced. 


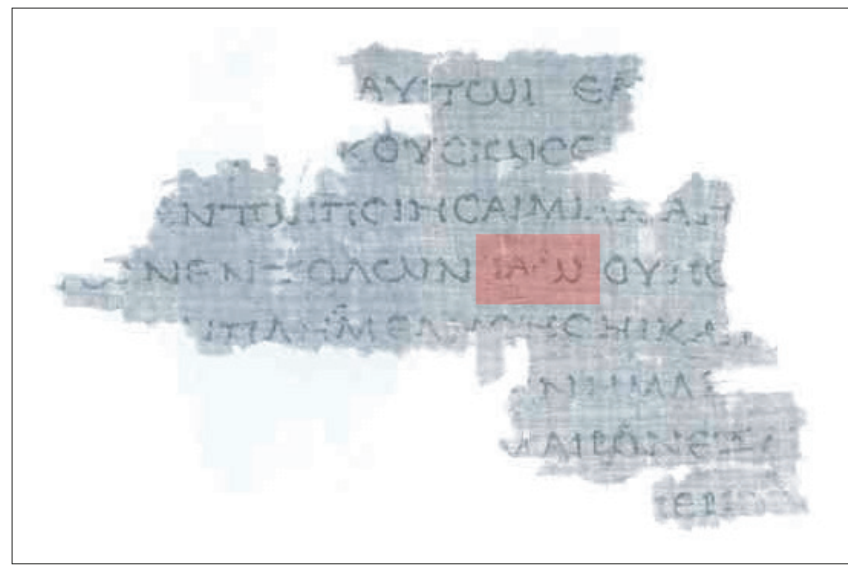

Source: See http://ccat.sas.upenn.edu/rak//lxxjewpap/4QLevB.jpg FIGURE 8: 4QLXXLev ${ }^{\text {b }}$ (Lv 4:27).

fragment 1 , line 5 where one would have expected a rendering for the term 4120 (4QLXXLev') does offer some possibilities. (cf. Rösel 2007:414-419).

\section{QLXXLevb (Lv 4:27)}

This fragment (Figure 8) reads IAW, which was the reason why the remainder of the 4Q120 fragments were 'reconstructed' with the term IAW. Without going into detail, two remarks should suffice. Firstly, it is not totally impossible that the scribe left an open space between ENTO $\Lambda \mathrm{WN}$ and $\mathrm{OY}$ with a later redactor inserting IAW. Secondly, one should not assume based on this single occurrence that this term was used throughout the manuscript. ${ }^{41}$ The point is that at a very early stage, the term IA $\Omega$ was considered an accepted transliteration of the term Yhwh but whether it was the general accepted term remains questionable. ${ }^{42}$

\section{P.Fouad 266b (848) (Dt 31:28-32:7)}

Figure 9 is an extract taken from P.Fouad 266b (848 second century BCE) attesting to Deuteronomy 31:28-32:7 content. The scribe left an open space, wide enough to insert either יהוה or אvplos written out. A latter redactor then inserted יהוה into the blank spaces (cf. Tov 2004:226). In 848 (plate 44 , col. 71.44ff) attesting to Deuteronomy 31:27 read יהוה tov $\theta \varepsilon o v$, whereas 847 (plate 51, col. IV) reads

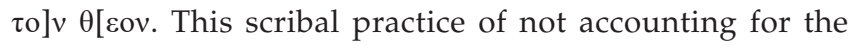
divine name at all by leaving an open space is not limited to P.Fouad 266b; P.Oxy 656 (905), a second century manuscript also attests to leaving an open space, which was later filled with an abbreviated form of the term кv́pıs. Reference was already made to 8HevXIIgr, Greek manuscripts (50 BCE-50CE), which reproduce the term יהוה using palaeo-Hebrew script.

With these three examples, if one includes 8HevXIIgr, there are four rendering possibilities for Yhwh:

41.Shaw (2014:33), is of a different view and argued for the prominence of this term He remarks that the onomasticon has 10 occurrences of $\mathrm{IA} \Omega$, all in expositions of biblical character's names.

42.The words $\delta \varepsilon \circ \mu \alpha \iota \sigma o \theta$, kupı l $\alpha \omega \Sigma \alpha \beta \alpha \omega \theta$... is depicted on a golden amulet dated to the third century $C E$. In the opening lines it calls upon $O \quad \theta \varepsilon \circ \varsigma A \beta \rho \alpha \alpha \mu, ~ o \theta \varepsilon \circ$

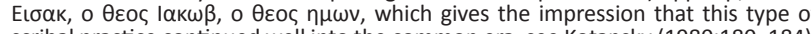
scribal practice continued well into the common era, see Kotansky (1980:180-184).
1. palaeo-Hebrew characters

2. IA $\Omega$

3. open space

4. square Hebrew characters. ${ }^{43}$

The transmission of the term יהוה in the Hebrew tradition, the translation of Yhwh with the term кv́ptos, and the subsequent reproducing and transmission of the latter term opens an array of possibilities on how to render the divine name. The кúpıৎ problem is multilayered, multifaceted and complex problem with no easy solution. To add to all of this, the use of the term кúpıs in Hellenistic specific Graeco-Roman literature offers another dimension to the kúpıs sroblem.

\section{A Hellenistic/Graeco-Roman concept of the

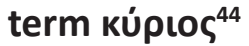

It should be stated upfront that a general Graeco-Roman concept underlying the term кúpıs is deliberately underplayed. The reason is because of the view held that such a concept does not contribute significantly enough to the NT kúpıs problem, but for the sake of perspective, the study will briefly allude to some Graeco-Roman sources.

Pliny the Younger's letter to Emperor Trajan after a visit to Bithynia in $112 \mathrm{CE}$ is insightful. The reason for this letter was to report on how Christians conduct themselves, he wrote:

They maintained, however, that the amount of their fault or error had been this, that it was their habit on a fixed day to assemble before daylight and recite by turns a form of words to Christ as a god.

Pliny's understanding of what qualifies and defines a ritual to be one 'as if it is dedicated to a god' made the Christian's habit of singing hymns dedicated to Christ guilty of treason. This issue is further amplified in the sense that, according to Pliny's investigator, some who claimed to be Christians, denied it later: 'All these too both worshipped your statue and the images of the gods, and cursed Christ'. The issue for Pliny is that Christ is venerated and worshipped as a god, as apposed to venerating the Emperor and pray to the 'traditional' Roman gods. This, of course, resulted in certain punishment, according to the response from Trajan, should they not deny Christ and worship their (Roman) deities. From this vantage point there is no other dominus ( $\kappa$ pios) other than the Emperor. The term кúpı $\zeta$ was also used when reference is made to Graeco-Roman deities. In three text fragments relating to a banquet invitation hosted by the god Sarapis is a good illustration. Nikephoros

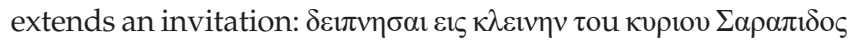
$\varepsilon v \tau \omega \lambda \circ \chi 1 \omega$ 'to dine in banquet with the lord Sarapis in birth-

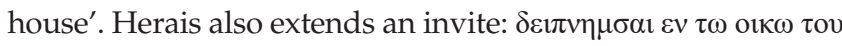

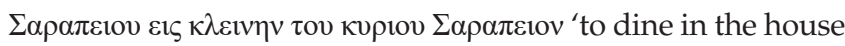
of Sarapis in banquet of the lord Sarapis', and $\kappa \alpha \lambda \varepsilon 1 \sigma \varepsilon$ o $\theta \varepsilon \circ \varsigma \varepsilon 1 \varsigma$

\footnotetext{
43. For a detailed list of how the oldest Greek manuscripts reproduced Yhwh, see Nagel (2017a:129-130).

44.See Nagel (2017b:89-110), for some remarks on Philo's understanding of the term kúpıos.
} 


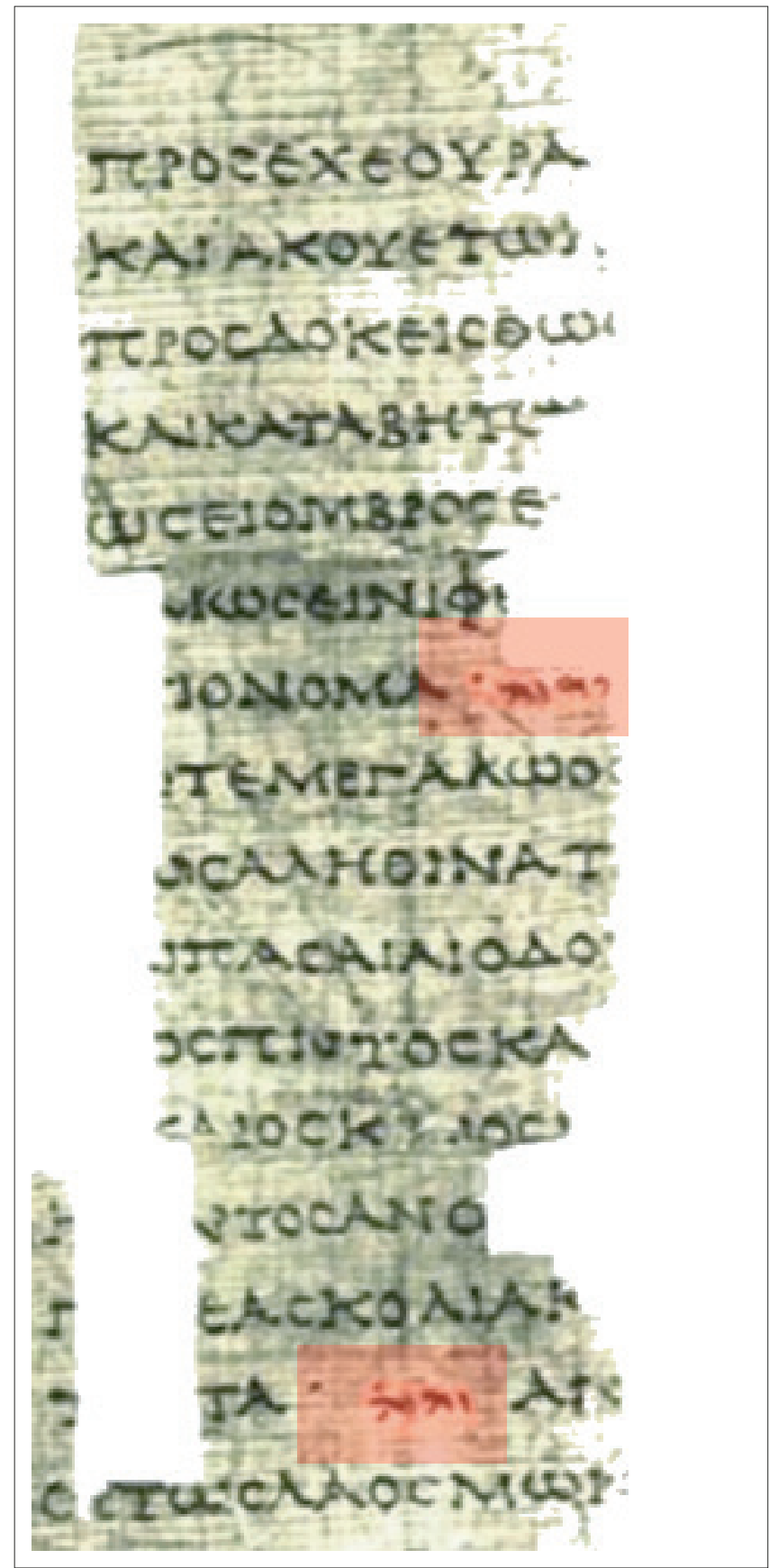

Source: See https://en.wikipedia.org/wiki/Papyrus_Fouad_266

FIGURE 9: P.Fouad 266b (848).

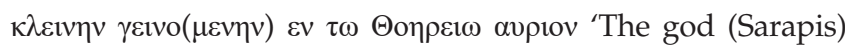
calls you to a banquet held in the Thoereion tomorrow' (Horsley 1984:6-9). In both instances the кúpıৎ terms are used to refer to Sarapis and is uncomplicatedly written out in full.

A document ${ }^{45}$ testifying to the repayment of loan states:

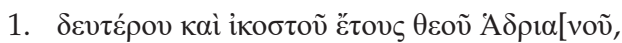

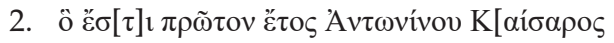

45.P.Oxy 98 (11.5 × $10 \mathrm{~cm}, 141-142 \mathrm{CE}), 1898$, in Grenfell and Hunt (eds. 1898:160) cf. P.Oxy 492, line 34 (the deification of emperor Nerva), and P.Oxy 483, line 14 referring to emperor Trajan as kúpioৎ and to deified Augusti in line 21. On a

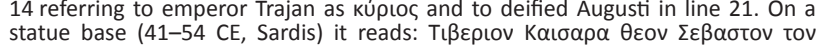

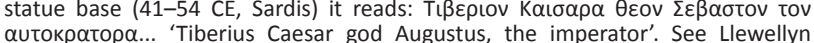
(2002:37); cf. A roman milestone (a notice of construction or repair roadwork), late (2002:37); cf. A roman milestone (a notice of construction or repair roadwork), late
first century refers to defied Vespasian 'divi Vespasiani' referred to later on in the

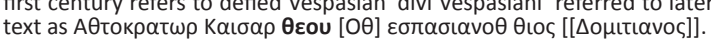

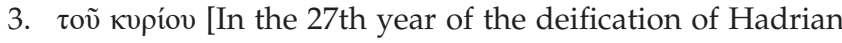
which is in the first year of emperor Antoninus' lordship.]

Interestingly noted here, is the ' $\theta \varepsilon$ ov ' of Hadrian and the ' $\tau$ ov кupiov' of Antoninus; the distinction is a deceased emperor (Hadrian) as opposed to the ruling emperor (Antoninus). The fluidness in the use of these terms could have been that in a Graeco-Roman context accounting for a 'sacred name' was not necessary, and that these terms were not influenced by the nomina sacra scribal practise. Pfeiffer's (2012:139-141) distinction between 'Imperial cult' and 'Emperor worship' is helpful at this juncture. He writes (in relation to the divine cult of the emperor being nothing more than an aspect of emperor worship): '...distinction of status between respective beings, rather than a distinction between their respective natures'. ${ }^{46}$ Gradel (2002:26) concluded: 'the worshipped emperor was not a god in an 'absolute sense', but he had a divine status....in relation to the worshippers'. This enlightens the notion of the distinction between the terms $\theta \varepsilon$ ó $\varsigma$ and кúpros. ${ }^{47}$

\section{The theology and kyriology of the New Testament ${ }^{48}$}

The NT kúpıs problem draws a matrix of complexities into a focused singularity. The explicit Old Testament citations are one such singularity, to be sure of those citations attest to the term кúpıs. The exegetical and hermeneutical reworking of the citations not only simultaneously contribute to the complexity of the problem, but also hold solution potential. Inferred from the cursory data covered under Section 'Transmission of the term kúpıos in the Greek tradition', it is fair to say that the term kópros found in the NT contains conceptual elements drawn from a general Hellenistic, Graeco-Roman context, but the true complexity of the matter is because it has an equation potential for the term Yhwh. This makes the NT Kyrios problem a theologically intricate one, with implications for the Christology and kyriology ${ }^{49}$ of the New Testament. The crux of the problem revolves around the sacred name Yhwh used for the Hebrew deity; the term kópros used as a potential Greek equivalent,

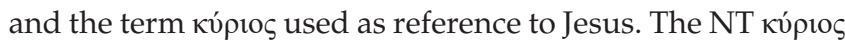
problem is also an exegetical and hermeneutical one; it is an inter and intertextual matter producing questions such as 'Should the use of the term kúpros in the citation be interpreted as referring to Yhwh?'; 'What is meant when Jesus is referred to as Kyrios?'; 'To what extent is the term кúproৎ re-interpreted in the NT?'; 'Was it even possible to put Jesus on par with Yhwh?'

46.Pfeiffer (2012:139-141), makes an important distinction between 'Imperial Cult' (honour reserved for the gods) and 'Emperor Worship' (worship given to mortals). Gradel (2002:26), aptly worded this distinction (in terms of the divine cult of the emperor being nothing more than an aspect of emperor worship) as 'distinction of status between respective beings, rather than a distinction between their respective natures'.

47.Gradel, Emperor Worship, p. 29.

48.See also Mark 1:1 (Is 40:3); 11:9 (Ps 118:25); 12:11 (Ps 118:22); 12:26 (Ex 3:6); 12:29-30 (Dt 6:5); Mark 12:10 (Ps 110:1); Jh 12:13 (Ex 23:40), 38 (Is 53:1).

49.This is a term which has its origins in my PhD research. 
Answers to these questions and a solution to the NT кúpros problem will be sought with the help of the Theos', David's and Jesus' speeches; to be clear, the explicit kúpros citations found in:

1. Theos' speech (Heb 1:10a [Ps 101:26a]; Acts 2:20-21 [Jl 2:31-32])

2. David's speech (Acts 2:25b [Ps 15:8a]; Mark 12:36 and Acts 2:34b [Ps 109:1a])

3. Jesus' speech (Mk 12:29b-30a [Dt 6:4c-5]).

\section{Theos' speech}

Hebrews 1:10a (Ps 101:26a) ${ }^{50}$ : The reason for showing the manuscripts here (Figures 10-12) is to prove the use of nomina sacra scribal practice. Codex S (Ps 101:26a) does not read any kúpı $\varsigma$ term, but it was added by a later redactor as a superscript (see the red block as indicated on the manuscript directly above). The Hebrews 1:10a section (Table 3) of codex S does account for a contracted кúpros term; the same applies to $\mathfrak{P P}^{46}$.

Hebrews 1:1-14 attest to a plethora of Old Testament citations, carefully and strategically structured in an attempt to affirm the identity of the son and to acknowledge his authority by allowing Theos to speak through the Hebrew Scriptures. ${ }^{51}$ Hebrews 1:10-12 is a continuation of what Theos is saying about the son as introduced by the

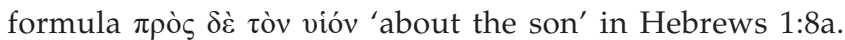
This is a continuation of what $\dot{\alpha} \theta \varepsilon \mathrm{è}_{\mathrm{s}}$ is saying about the son in contrast with the angels (cf. Heb 1:5a, 6a, and 7a). In Hebrews 1:10-12 the author relies on the prayer addressed to kv́pios in Psalms 101:26-28 to express what ó $\theta \varepsilon$ ò supposedly thought about the son. The author's strategy to have ó $\theta$ cò speak about the son through the Old Testament citations is both risky and strategically ingenious allowing ó $\theta$ \&ò $\varsigma$ to speak in such a manner would certainly accrue status and authority for the son, but compiling the various literary contexts could cause some confusion. For example, if one assumes that the definite article o and noun $\theta$ sò $\varsigma$ is calling a Hebrew deity to mind, and if one accepts that Psalms 101:26-28 is a Psalm about kúpros as in Yhwh, and if Yhwh is the Hebraic deity, then the vocative form of the

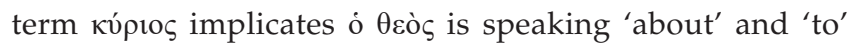
himself. It is not per se problematic for a deity to speak about to him or herself, but from the introduction formula (1:6a, 7a and $8 a)$ it is clear that 0 e $\theta$ ò is speaking about the son. Was this done by accident? Did the author lost track of who is saying what and about whom, or is this a case of equating the son with Yhwh? ${ }^{52}$

50.The theological effect and significance of this citation has been worked out in more detail in Nagel (2019:557-584)

51.Steyn (2009:341-359), noted that the LXX versions of these Psalms open up the possibility for a Christological interpretation, 341. Steyn (2010:82), also wrote that the third pair of quotations, Ps 44:7-8 (Heb 1:8-9) and Ps 101:26-28 (Heb 1:10-12) in the catena (with no traces in the tradition of such an existing combination prior in the catena (with no traces in the tradition of such an existing combination prio
to Hebrews), 'Both deal with the theme of the eternal reign of the Son who is addressed as 'God' (if $\theta$ còs is taken as a vocative in this instance).

52.Steyn (2010:82), is of the opinion that the Son is being addressed as $\theta$ cò in Hebrews 1:8 and kúpเe in Hebrews 1:10.6

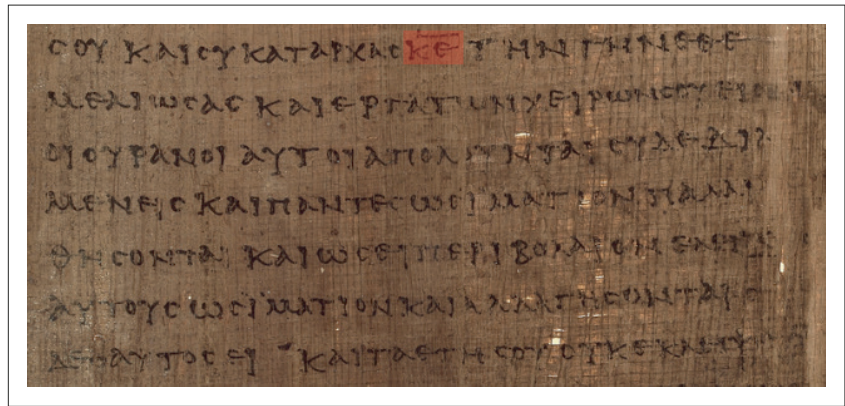

Source: The Center for the Study of New Testament Manuscripts, n.d., viewed 31 March 2020, from http://www.csntm.org/manuscript/View/GA_P46 FIGURE 10: Papyri 46 (Heb 1:8-12).

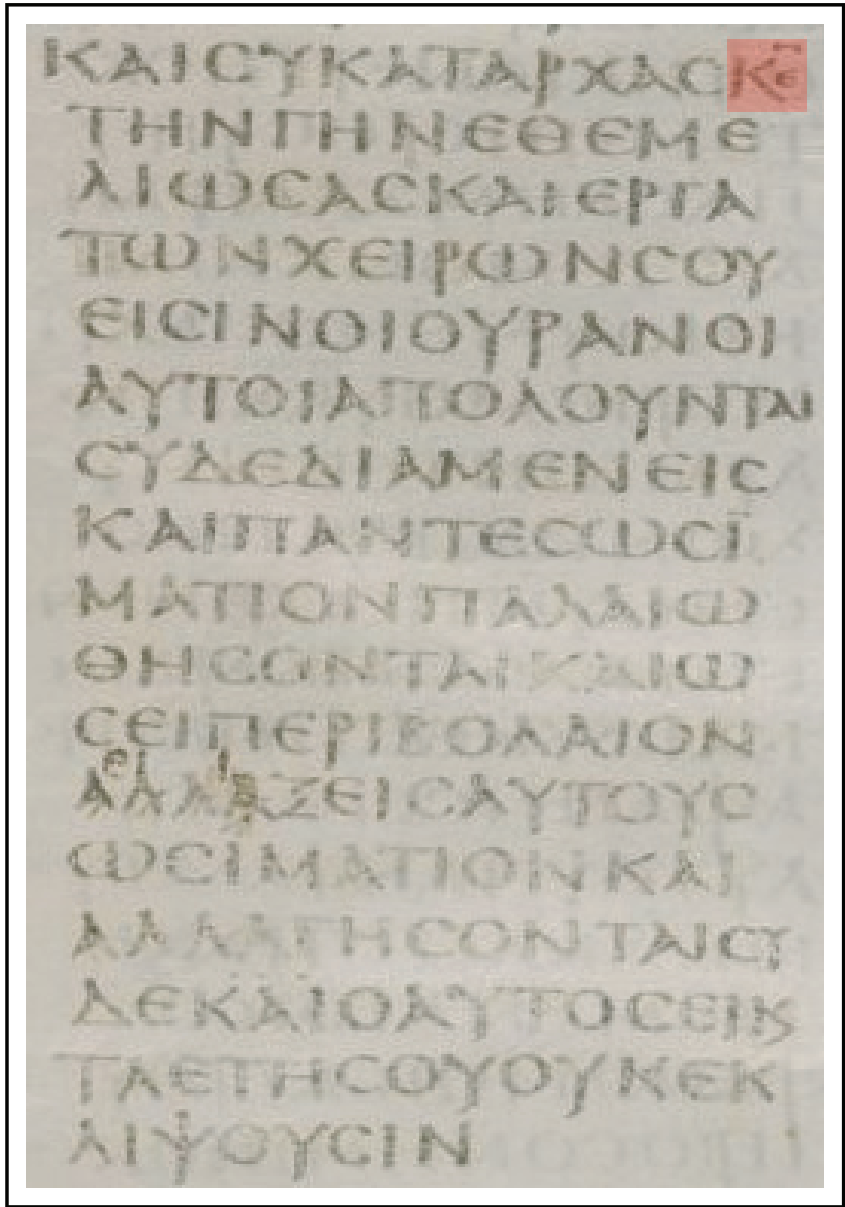

Source: See https://www.codexsinaiticus.org/en/manuscript.aspx

FIGURE 11: Codex Sinaiticus (Heb 1:8-12).

Intertextually speaking the Psalmist calls upon кúpıs, in the vocative case, to listen to his prayer (Ps 101:2). In Psalms 101:13 кúpro $\zeta$ is again referenced using the vocative case; here

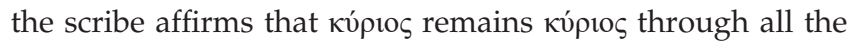
ages of time. The vocative use in Psalms 101:26a, kópıoৎ is recognised as the one who laid the foundation of the earth, from the very beginning, whereas Psalms 101:26b acknowledge the fact that it is because of the works of his (kurios') hands that the heavens exist. ${ }^{53}$ Conceptually, there should be little doubt that the kv́pios of Psalms 101:26 is the $\theta \varepsilon$ ó $̧$ of Genesis 1:1 and 2:4b (cf. Steyn 2010:110-111). From an

53.It is interesting to note that both references to the term kúpios introduce two possible additions; verses $13-23$ and verses $26-29$ respectively, both defined as hymnic sections; cf. Steyn (2010:103-104). 


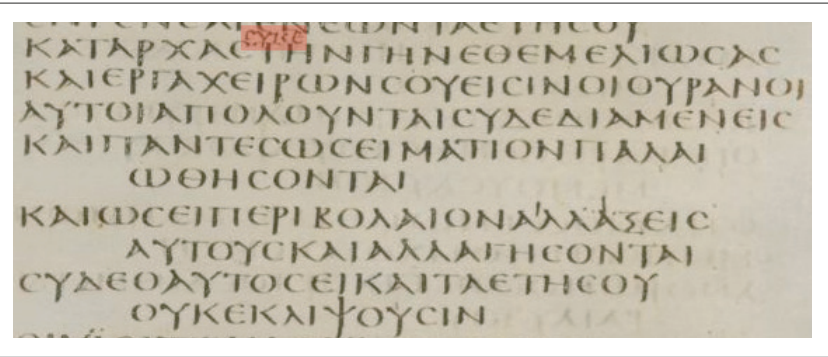

Source: See https://www.codexsinaiticus.org/en/manuscript.aspx

FIGURE 12: Codex Sinaiticus (Ps 101:26-28). ${ }^{54}$

TABLE 3: Hebrews 1:10a (Ps 101:26a).

\begin{tabular}{|c|c|c|c|}
\hline & Hebrews $1: 10 a$ & & Ims 101:26a \\
\hline$N^{28 \text { th }}$ & P46 & Codex S & Codex S \\
\hline 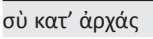 & кат $\alpha \rho \chi \alpha \varsigma$ & 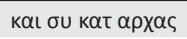 & кат $\alpha \rho \chi \alpha \varsigma$ \\
\hline кúpıє, & $\overline{\mathrm{K} \varepsilon}$ & $\overline{\mathrm{K \varepsilon}}$ & \\
\hline $\begin{array}{l}\text { Tท่v } \vee \tilde{n} v \\
\varepsilon \dot{\theta} \varepsilon \mu \varepsilon \lambda i \omega \sigma \alpha \varsigma\end{array}$ & $\begin{array}{l}\tau \eta v \vee \eta v \\
\varepsilon \theta \varepsilon \mu \varepsilon \lambda \iota \omega \sigma \alpha \varsigma\end{array}$ & $\begin{array}{l}\tau \eta v \vee \eta v \\
\varepsilon \theta \varepsilon \mu \varepsilon \lambda t \omega \sigma \alpha \varsigma\end{array}$ & $\begin{array}{l}\eta v \vee \eta v \\
\varepsilon \theta \varepsilon \mu \varepsilon \lambda \iota \omega \sigma \alpha c\end{array}$ \\
\hline
\end{tabular}

NA, Nestle-Aland.

Note: See the detailed text critical considerations in Steyn (2010:105-109).

intertextual point of view, Hebrews 1:2b-c suggest that the son is positioned as heir of everything through whom $\theta \varepsilon$ ó $\varsigma$ made all the ages.

This sounds somewhat different from what is presumably proposed in Hebrews 1:10a-b that kv́pı creator, he is the one who laid the foundations of the earth (Heb 1:10a) and created the heavens (Heb 1:10b), whereas in the former (Heb 1:2b-c) the son is the heir, the medium through which all has been created. The author appears to be inconsistent if (1) one draws a distinction between $\theta \varepsilon$ co $\varsigma$ in Hebrews 1:2b-c and кúpios in Hebrews 1:10b and (2) if кúpıs in Hebrews 1:10b does not refer to the son. What seems to be more plausible is that the author did not think through the implication of the term kv́ptos in Hebrews $1: 10 \mathrm{~b} .{ }^{55}$ But how does these arguments hold up in the textual unit Hebrews 1:8-9 (Ps 44:7-8) and Hebrews 1:10-12 (Ps 101:26-28), both of which are presented as Theos' speech about the son (Heb 1:8a)?

In Hebrews $1: 8 b$ it is said about the son that his (second person, personal pronoun) throne is $\dot{o} \theta \varepsilon \mathrm{s}_{\zeta}$ and therefore it is a throne forever and that his (implying the son's) kingdom is a rule that can be characterised by uprightness (Heb 1:8c). It is further declared that the son loves righteousness but hates lawlessness (Heb 1:9a). The second person speech in Hebrews $1: 8 b-9 b$ implies that the Psalmist directs his Psalm to the son, the king and son of all sons of Cyrus (cf. Ps 44:1-2). In Hebrews $1: 9 \mathrm{~b}$ it is ó $\theta \varepsilon$ ò $̧$ as the o $\theta \varepsilon$ ó $\varsigma$ of the king (cf. Psalm 44) and by implication the son, who anoints the king and son. It is at this point that the author introduces the Psalm 101:26-28 citation. It seems rather obvious that $\sigma$ v̀ (Heb 1:10a) also refers to the son, as does all the other second person pronouns in Hebrews $1: 8-9$. If this is the case, then the vocative use of the term

54.4QPsb col. XXII frgs. 15 also does not make any reference to Yhwh; a tradition upheld by Codex S. The LXXGött (Ps 101:26) does, however, account for the term kúplos in its vocative form.

55.According to Church (2016:269-286), the exalted son in the Psalm context is now the 'Lord' in Hebrews 1:10; meaning the son. кúplos can only refer to the son, but does it? The suggestion here is that the ov in Hebrews 1:10a, to be sure the vocative

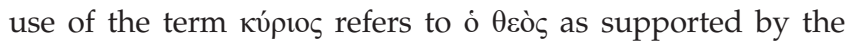
connection drawn in the source text (Ps 101). The reason for this suggestion is that whilst Psalm 44:7-8 (Heb 1:8-9) is

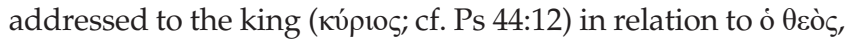

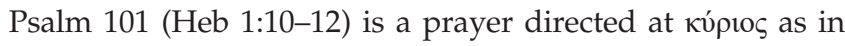
Yhwh. What does the author achieve with such a reading? How does it contribute to establishing the authority of the son? The answer is that in Hebrews 1:8-9 the kingship of the son in relation to o $\theta \varepsilon$ ò $\varsigma$ is brought into focus, so much so that the son's throne is ó $\theta \varepsilon$ c̀s. But in Hebrews 1:10-12, the кúpı s as in Yhwh, is brought into play. The author had to account for the fact that his readers might have understood $\sigma \grave{v} \kappa \alpha \tau$ ' $\alpha \rho \chi \alpha ́ s$,

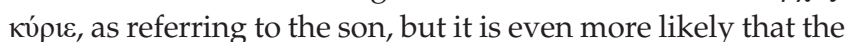
Yhwh characterisation of 0 i $\theta$ ò $\varsigma$ is preferred as the more appropriate reading for a Hellenic-Judaic audience. ${ }^{56}$ If Hebrews 1:10-12 awoke a sense of ambiguity, it would have been laid to rest with the citation taken from Psalm 109:1 (Heb 1:13b). ${ }^{57}$ In Hebrews 1:13a, the author returns to the topic of angels, asking whether Theos has ever said to the angels to $\kappa a ́ \theta$ ov $\dot{\varepsilon} \kappa \delta \varepsilon \xi 1 \tilde{\omega} \nu \mu \mathrm{ov}$ 'to be seated on my right hand' (Heb $1: 13 b)$. It is noteworthy that $\mu$ ov by implication refers to Theos in this case, which begs the question why is it not possible to

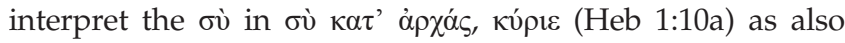
referring to Theos? On the one hand the citation in Hebrews 1:10-12 (Ps 101:26-28) exemplifies the кúpıs problem, but on the other hand it offers theological perspectives necessary to find an amicable solution.

Acts 2:20-21 (Joel 3:4-5a): The manuscript data appear intact, with no alternatives suggested for the term kópios, but this does not suggest that all is what it seems, it might just be a matter of scribal 'cover-up'. Be it as it may, the literary ' $\kappa$ 'vı $\varsigma^{\prime}$ context does not disappoint in offering support to the kúpı problem. The events that would unfold in Acts 2:20-21 begins with Acts 1:6 when those who gathered around him addressed Jesus by using the term kúpic. They wanted to know whether the time has come for the kingdom of Israel to be revealed. They kept referring to Jesus by using the term кúpıo̧ even after Jesus ascended into heaven (cf. Acts 1:9-11). His followers also referred to his earthly ministry with the

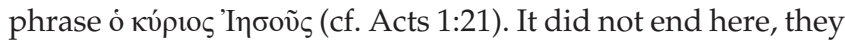
prayed to him, calling upon him as kúpıe (Acts 1:24). The second chapter of Acts introduce the 'day of Pentecost' followed by Peter's first speech in Acts 2:14-40. It is within this context that the Joel $3: 1-5$ citation $^{58}$ is implemented, of which Joel 3:4-5a (Acts 2:20-21) is of interest (cf. Table 4).

There is no obvious reason why one should not interpret the two kv́pı references in Acts 2:20-21 as referring to the same entity as the term кúpros in Acts 1:6, 21 and 24, hence, Jesus. This raises two questions. The first is whether the author was cognisance of the fact that the term kúpros in Acts 2:20-21

56.Steyn (2010:111), remarks that principally, with the inclusion of kup o. in the LXX the activities in Psalms 101 could be transferred to Christ.

57.Psalm 109 presents itself as 'Yahweh's oracle,'; cf. Steyn (2010:114).

58.Wadi Murabaat, col. II reads the expected יהוה 
TABLE 4: Acts 2:20-21 (JI 3:4-5a).

\begin{tabular}{|c|c|c|c|}
\hline \multicolumn{3}{|c|}{ Acts 2:20-21 } & \multirow{2}{*}{$\begin{array}{l}\text { Joel 3:4-5a } \\
\text { Codex S }\end{array}$} \\
\hline$N^{28 t h}$ & $\mathfrak{P 7 4}$ & Codex S & \\
\hline 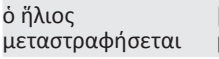 & $\begin{array}{l}\text { [o } \eta \lambda \text { เo૬] } \\
\mu \varepsilon \tau \alpha \sigma \tilde{\tau}[\tau \alpha \phi \eta \sigma \varepsilon\end{array}$ & $\begin{array}{l}\text { o } \eta \lambda เ \text { เо } \\
\mu \varepsilon \tau \alpha \sigma \tau \rho \alpha \phi \eta \sigma \varepsilon \tau \alpha \iota\end{array}$ & $\begin{array}{l}\text { o } \eta \lambda \iota{ }^{\prime} \\
\mu \varepsilon \tau \alpha \sigma \tau \rho \phi \eta \sigma \varepsilon \tau \alpha \iota\end{array}$ \\
\hline 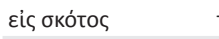 & 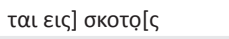 & 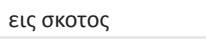 & عાৎ бКото \\
\hline 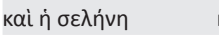 & к $\alpha \iota \eta$ $\sigma \varepsilon \lambda \eta] v \eta$ & 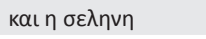 & 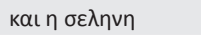 \\
\hline 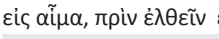 & $\varepsilon ı \varsigma \alpha ![\mu \alpha \pi \rho ı v] \varepsilon \lambda \theta \varepsilon ı v$ & $\varepsilon \iota \varsigma \alpha \iota \mu \alpha \pi \rho ı v \varepsilon \lambda \theta \iota v$ & $\varepsilon \iota \varsigma \alpha \iota \mu \alpha \pi \rho ı v \varepsilon \lambda \theta \iota v$ \\
\hline 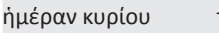 & $\tau \eta[v \eta \mu \varepsilon \rho \alpha v \overline{K U}]$ & $\eta \mu \varepsilon \rho \alpha v \overline{\kappa u} \tau \eta(v)$ & $\eta \mu \varepsilon \rho \alpha v \overline{\kappa U} \tau \eta v$ \\
\hline 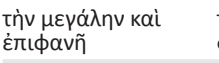 & 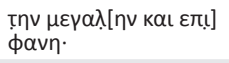 & $\mu \varepsilon \gamma \alpha \lambda \eta \nu$ & 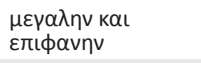 \\
\hline 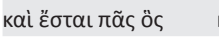 & 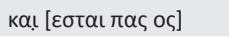 & - & 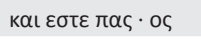 \\
\hline 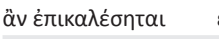 & $\varepsilon \alpha v \varepsilon \pi \iota k \alpha \lambda \varepsilon[\sigma \eta$ & - & $\varepsilon \alpha v \varepsilon \pi \iota k \alpha \lambda \eta \tau \alpha \iota$ \\
\hline tò övo $\mu \alpha$ kupíou & 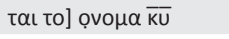 & - & to ovo $\mu \alpha \overline{\mathrm{KU}}$ \\
\hline$\sigma \omega \theta \eta \dot{\sigma \varepsilon t \alpha \iota ~}$ & $\sigma \omega[\theta \eta \boxminus \varepsilon \varepsilon \tau \alpha \iota$ & - & $\sigma \omega \theta \eta \sigma \varepsilon \tau \alpha \iota$. \\
\hline
\end{tabular}

NA, Nestle-Aland.

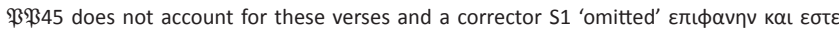

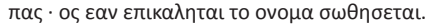

could imply Yhwh. The second related question is whether the author re-interpreted the term кúptos to give it a more Hellenistic flavour. ${ }^{59}$ What is clear is that the author cites Joel 3 extensively, which makes it highly likely that he had a fairly good understanding of the literary context. In the Hebrew version of Joel, the term Yhwh is used throughout, and if one assumes that the MT text represents a possible Hebrew vorlage then there is no reason not to interpret the term кúpios as a Greek equivalent for Yhwh. There is no evidence to suggest otherwise, except for the fact that some of the oldest Greek manuscripts attesting to Joel might have read palaeoHebrew script for Yhwh. Not only that, there is no hard evidence to prove that an uncontracted kv́pios term was used to translate the term Yhwh. One should assume, for the sake of the argument, that conceptually at least, the term кúpıs represented Yhwh in the source text, but when the text was applied to the target text, is was re-interpreted. There are at least two arguments opposing a Yhwh meaning assigned to the term kópios in these instances:

1. In Acts 2:17a it is ó $\theta \varepsilon$ ć $̧$ who says something about what will happen during these last days. If this is so, and if кúpios represent Yhwh and if Yhwh in turn is considered the Elohim of the Old Testament then it would imply that o $\theta \varepsilon$ ć $\zeta$ is speaking about himself in the third person. To counter this circular reasoning, a new meaning is ascribed to the term kv́pros, the same meaning it has in Acts 1:6, 21 and 24; that of an authoritative figure.

2. If Yhwh was meant with the two occurrences in Acts 2:20-21, why would it be necessary to use the term $\theta \varepsilon$ co elsewhere in the text?

One can also argue in reverse order; if the two kúpıs represented Yhwh as the Elohim of Israel, why would it be necessary to make it explicit that $\theta \varepsilon$ ć $̧$ wants to say something? Why introduce Acts 2:17-21 as Theos' speech if it was so obvious that the term kúpios called a Hebrew deity to mind?

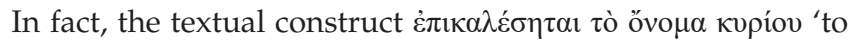
call the name of the lord' is already a shift away from Yhwh

59.Blumhoffer (2016:499-516), certainly seems to think so. He is of the opinion that Luke did not receive a text with the 'changes' compared with the Septuagint Wuke did not receive a text with the 'changes' compared with the Septuagint. moves, he wrote: 'these echoes suggest that Luke has quietly and intentionally moves, he wrote: 'these echoes suggest that Luke has quietly and intentionally
evoked a correspondence between Old Testament prophecy and the Day of Pentecost in Acts.'

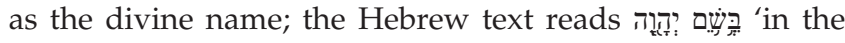
name Yhwh'. The power of submission is to do it in the name, the 'divine name'. In Joel the term kópros becomes a title of someone with a significant name, and this name is interpreted in Acts 2:20-21 as Jesus. The term kúpros in Acts 2:20-21 (Joel 3:4a-5) is not a reference to Yhwh, but to a lord with a meaningful name, reinterpreted as Jesus. The Theos' speeches make it extremely difficult to interpret the use of the kúpı term in Hebrews 1:10a and Acts 2:20-21 as referring to Yhwh. It helps to get rid of the ambiguity and by doing so contributes to finding a solution to the NT кúpros problem.

\section{David's speech}

Acts 2:25b (Ps 15:8a): The inverse dualistic (solution-problem) nature of the кúpıs problem has been highlighted by way of the so-called Theos' speeches, but does David's speeches also hold solution potential? In Acts 2:25a, the introductory

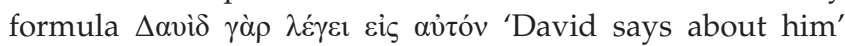
introduces a citation taken from Psalms 15:8-11; Psalm 15 is a stele inscription pertaining to David submitting himself to Kyrios and by implication Yhwh. It is doubtful if the author wanted his readers to hear that David is saying something about Yhwh; he probably wanted them to hear what the 'great' king David said about Jesus as the Kyrios. The author interprets David's foresight as referring to the resurrection of

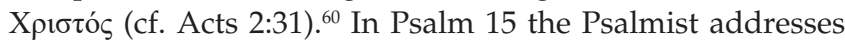
Kyrios as in Yhwh throughout, but the author of Acts extracted verse 8-15 to serve his purpose of prophetic foresight (cf. Ps 15:8), the resurrection of the devoted one (cf. Ps 15:10), in this case Christ (cf. Acts 2:31). The Psalm, however, speaks of the devoted or pious one, such as king David, whose soul will not be abandoned by Kyrios to Hades. How are these linguistical 'transfigurations' and 'transformations' of кúpıs from being Yhwh to kv́pıs as in Jesus the Messiah and David being the pious one to the one who speaks in the third person possible? This reimagination is made possible by the reference to the pious one in Psalms 15:10, introducing the Psalms 15:8-11 citation as Davidic speech, the term kúplos in its accusative form and the literary context of Acts 2:17-28; both the Joel 3:1-5 and Psalms 15:8-11 citation form part of Peter's first speech. The term кúpı interpreted as the same kúpros in Acts 2:20 and 21, namely Jesus, the Messiah.

Mark 12:36 ${ }^{61}$ and Acts 2:34b (Ps 109:1a): The citation in Acts 2:34b in Table 6 follows the same trajectory as Acts 2:25b; the uttering of the term кúpı words reflect Psalms 109:1a and is also introduced in Mark $12: 36 b^{62}$. One can deduce at least two text traditions from the data, the one reading the first kúploc term with and without a

60.Trull (2004:432-448), remarks that Acts $2: 22-36$ is Peter's Christological argument, which includes the attestation of Jesus through his earthly works. He goes on to say that it was impossible for Jesus to remain dead because David had prophesied that the Messiah would rise, this is the reason for the Psalms 16:8-11 citation, according to him.

61.Cf. Matthew 22:44b; Luke 20:42b and Hebrews 1:13b.

62.The use of Psalm 109:1a in Mark 12:36b is proof that from a very early stage in the Christian tradition, which probably started with Paul, the elevated authoritative position of the Messiah as Kyrios was accepted. Undeniably, the new king of Israel is Kyrios as in Jesus; cf. Jh 12:12-13. The latter is also implied in Hebrews 1:8-9 (Ps 44:7-8). 
TABLE 5: Acts 2:25b (Ps 15:8a).

\begin{tabular}{|c|c|c|}
\hline \multicolumn{2}{|c|}{ Acts $2: 25 b$} & \multirow{2}{*}{$\begin{array}{l}\text { Psalms 15:8a } \\
\text { Codex S }\end{array}$} \\
\hline$N^{28 t h}$ & Codex S & \\
\hline$\pi \rho о \circ \rho \omega \dot{\mu \eta \eta}$ & $\pi \rho о o \rho \omega \mu \eta(v)$ & $\pi \rho о o \rho \omega \mu \eta v$ \\
\hline 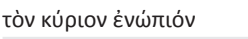 & 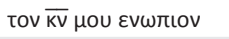 & $\tau o v \overline{K V} \varepsilon v \omega \pi i o v$ \\
\hline 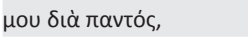 & $\mu \circ u \delta\llcorner\alpha \pi \alpha(v) \tau o \varsigma$ & 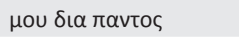 \\
\hline 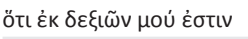 & 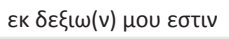 & 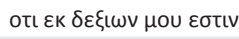 \\
\hline ïv $\alpha \mu \eta \dot{~} \sigma \alpha \lambda \varepsilon \cup \theta \tilde{\omega}$. & $\ddot{\imath} v \alpha \mu \eta \sigma \alpha \lambda \varepsilon \cup \theta \omega$ & $\ddot{\imath} v \alpha \mu \eta \sigma \alpha \lambda \varepsilon \cup \theta \omega$ \\
\hline
\end{tabular}

NA, Nestle-Aland.

TABLE 6: Mark 12:36 and Acts 2:34b (Ps 109:1a).

\begin{tabular}{|c|c|c|c|c|}
\hline \multicolumn{2}{|c|}{ Mark 12:36b } & \multicolumn{2}{|c|}{ Acts $2: 34 b$} & \multirow{2}{*}{$\begin{array}{l}\text { Psalms 109:1a } \\
\text { Codex S }\end{array}$} \\
\hline $\mathrm{NA}^{28 \mathrm{th}}$ & Codex S & $N^{28 t h}$ & Codex S & \\
\hline 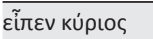 & $\varepsilon \operatorname{\varepsilon i\pi } \varepsilon(v) \circ \overline{\mathrm{K \zeta}}$ & 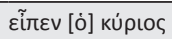 & $\varepsilon เ \pi \varepsilon \mathrm{V} \overline{\mathrm{K}}$ & $\varepsilon เ \pi \varepsilon v \circ \overline{\mathrm{K} \zeta}$ \\
\hline 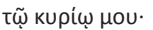 & $\tau \omega \bar{\kappa} \bar{\omega} \mu \mathrm{ou}$ & 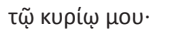 & $\tau \omega \bar{\kappa} \bar{\omega} \mu \mathrm{ou}$ & $\tau \omega \bar{\kappa} \bar{\omega} \mu \mathrm{ov}$ \\
\hline
\end{tabular}

NA, Nestle-Aland.

definite article. The reason for this is to draw a distinction between the first and second kúpıc term; the first is a reference to Yhwh and the second to a king. In the case of Mark 12:36b the author as Jesus argued against the notion that the Messiah is the son of David. Jesus' argument is that how can the Messiah be the son of David if David himself calls кóptos, кúproৎ (cf. Mk 12:37). The problem with such an argument is as follows:

1. In Psalm 109 context it is not David speaking, but the Psalmist.

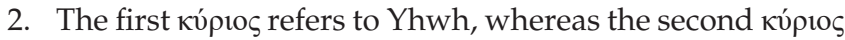
refers to David (Ps 109:1a).

3. The direct speech in Psalms 109:1b is that of a kúpros in terms of Yhwh.

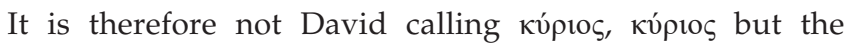
Psalmist who refers to kúpios (as in Yhwh, the first кúpios term) as kúpıs who in turn calls David, the Psalmist's

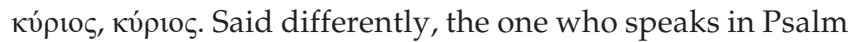
109:1a is кúpros in the sense of Yhwh, and the one who Yhwh is saying something about is also kúproc in terms of David as king. This is written by the Psalmist who allows Yhwh to say something about the Psalmist's king. ${ }^{63}$ In the Lukan version, David is speaking in the 'book of the Psalms' about the Messiah being the kv́pios. ${ }^{64}$ It is clear from the Psalm 109:1b citation that the Synoptic Gospels differentiate between the term кúpios (second term) used for the Messiah and the term kúpıs used as equivalent for Yhwh (first occurrence). In the context of Psalm 109 the second kv́pros is an appellative, signifying authority and rule. The right hand in this case is reserved for king David, but it is reinterpreted in the NT as reserved for the Messiah or the son. ${ }^{65}$ The ultimate objective is to counter the argument that the Messiah is just another ruler of Israel from the lineage of king David. In the case of Hebrews 1:13b the authoritative position of the son (sitting at the right hand) is set off against the inferior position of the angels. The difference is that in the latter case it is Theos who speaks and not David. To reiterate, by placing the words of Psalms 109:1a on the lips 63.cf. Matthew 22:43.

64.Cf. Luke 20:41.

65. Hebrews 1:13b. of king David implies that the author understood the first

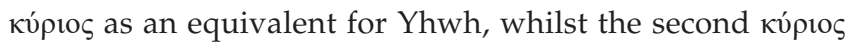
term is interpreted as the authoritative position of the Messiah, namely at the right hand of Yhwh. The duplication of the term кúpıs complicated the matter, but this duplication allows one to infer that the sacred thrust of the 'name' Yhwh got lost in translation. A more appropriate translation for יהוה לאדני (Ps 110:1b as it may, the NT authors succeeded in convincing their audience of the authoritative position of the Messiah at the right hand of Kyrios as in Yhwh, elevating his position as more authoritative than king David.

The version in Acts 2:34b has no interest in addressing the Messiah being the son of David issue, but the aim is to support Acts 2:31; the foreseeing of David, even though David did not ascend into heaven he still knew that عĩ $\pi v$ [ó]

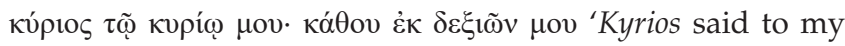
Kyrios sit on my right hand'. The words in Acts 2:36 summarise the author's intent: $\alpha \sigma \varphi \alpha \lambda \tilde{\omega} \varsigma$ ỡv $\gamma 1 v \omega \sigma \kappa \varepsilon \dot{\tau} \omega \pi \tilde{\alpha} \varsigma$

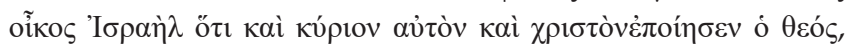

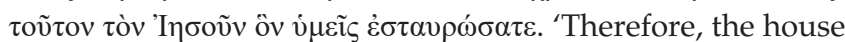
of Israel should undoubtedly know that Theos made him both Kyrios as in 'authoritative figure' and 'Messiah' as in divine liberator, this is Jesus whom you have crucified'. In summary, the solution to the кúpios problem offered here is the reinterpretation of Psalms 109:1b. To be sure, allowing David to speak and because of his speech the use of the kv́ptos term in Psalms 109:1b in relation to Yhwh and Jesus is cleared of any indistinctness.

\section{Jesus' speech}

Mark 12:29b-30a (Dt 6:4c-5): The Greek text tradition once again appears to be intact, with minor variations in the Greek tradition (Table 7). In the case of Mark 12:28-30, scribes came up to Jesus to ask him what is the first commandment of them all? The Markan Jesus then responded by quoting from Deuteronomy 6:4a-5. There is no clearer evidence, at least in the mind, that both Jesus and the author conceptually distinguishes himself from the one and only кúpros ó $\theta \varepsilon$ cò in the sense of Yhwh, the one and only Elohim of Israel. Earlier on in the narrative (cf. Mk 12:18-27) some Sadducees came to Jesus, to challenge him on the resurrection. He responded to them by quoting from the book of Moses (Ex 6:15), which says that Theos is the Theos of the Patriarchs, the Theos of the living, not the dead. The fact that Deuteronomy $6: 4 b-5$ is cited by Jesus simplifies the кúpros problem. There are no discrepancies, uncertainties or clarifications needed; the content cited is a living tradition, which Jesus simply repeats, as one does as a law-abiding Judean. Deuteronomy 5-6, amongst other text, were part of Hebrew texts on vellum placed in a small leather box called a phylactery, worn by Jewish men at morning prayer as a reminder to keep the law. These texts were recited repeatedly and would have been known of by heart. It is against this backdrop that one should interpret Jesus' response. He (Jesus) is merely reciting this morning prayer that the Yhwh, the Theos of Israel is the one and only Kyrios. The second reference to the term kóptos is to emphasise the 
TABLE 7: Mark 12:29b-30a (Dt 6:4c-5).

\begin{tabular}{|c|c|c|}
\hline \multicolumn{2}{|c|}{ Mark 12:29b-30a } & \multirow{2}{*}{$\begin{array}{l}\text { Deuteronomy } \\
6: 4 c-5 \\
\text { Codex S } \\
\end{array}$} \\
\hline $\mathrm{NA}^{28 \mathrm{th}}$ & Codex S & \\
\hline 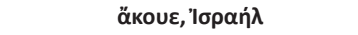 & $\alpha$ kou $\overline{\operatorname{t\eta }} \bar{\lambda}$ & Not available \\
\hline 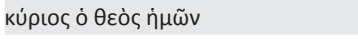 & $\overline{\mathrm{K} \varsigma} \circ \overline{\theta \varsigma} \eta \mu \omega \nu$ & - \\
\hline 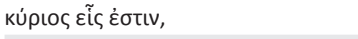 & $\overline{\mathrm{K \varsigma}} \varepsilon \mathrm{\iota \iota} \varepsilon \sigma \tau \mathrm{t}(\mathrm{v})$ & - \\
\hline 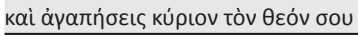 & 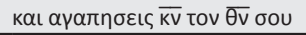 & - \\
\hline \multicolumn{3}{|l|}{ NA, Nestle-Aland. } \\
\hline \multicolumn{3}{|c|}{ 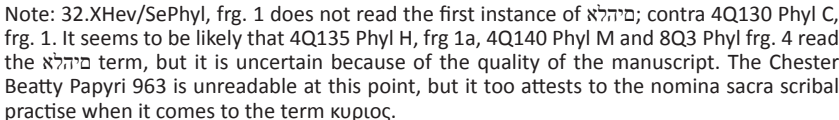 } \\
\hline
\end{tabular}

dominion and authority of Yhwh as the one and only Theos. The fact that this is Jesus' speech and the nature of the content of the speech, contributes to a better understanding of the term kópıs and the problem it might pose.

The explicit кúpros citations in combination with the introductory formulae characterised as Theos', David's and Jesus' speech is the most effective way to determine whether referring to Jesus as Kyrios is meant in the Yhwh sense or not. These speeches and the content placed on the lips of Theos, David and Jesus, respectively, cleared the NT кúpıs problem from any ambiguity or vagueness.

\section{Conclusion}

The conclusion is that there is no decisive and final solution for the NT кúpıs s problem. In fact, there will never be a single solution for this multilayered and interconnected problem. The only option is to keep on addressing every single aspect of the kúpros problem against a multilayered complex background. The NT кúpios problem, should therefore never just be a NT problem, it will always be a NT - Old Greek (LXX) problem. This is precisely what the study set out to illustrate. In addition to illustrating the interwoven complexity and intricacies of the problem, the study also draws these multilayered complexities into a singular focus, namely the explicit kúpı citations. To be precise, those citated content were placed on the lips of Theos, David and Jesus, which the study refers to as speeches. The study shows that these respective speeches amplify the problem whilst taking a step towards a possible solution. The best possible inference to draw when arguing from the vantage point of these speeches is that (1) the term кúptos as an equivalent for יהוה is a theological rendering designating 'master of the universe,' and (2) the articulated kúptos, the absolute form is ascribed to Jesus not in the Yhwh sense, but is reinterpreted to mean the 'master of the NT universe. What these speeches have revealed is that Yhwh as in kúpios is still the Theos of Israel who is kúpros as in the ultimate master and ruler overall, and that Jesus becomes the kóptos, embodies the кúpıs and rules as master of the NT world and beyond. When the term kúpıø was used as a potential equivalent for Yhwh, the divine name for a Hebrew deity was stripped of its sacred character and lost the credentials of having a 'divine name'. The term kópıos on the lips of Theos, David and Jesus is a humble, non-deliberate attempt to make 'the name' divine again; it reignites its sacred character. By ascribing this кúpış to Jesus, makes Jesus the new 'divine' name.

\section{Acknowledgements Competing interests}

The author declares that he has no financial or personal relationships that may have inappropriately influenced him in writing this research article.

\section{Author's contributions}

P.N. is the sole author of this research article.

\section{Ethical considerations}

This article followed all ethical standards for research without direct contact with human or animal subjects.

\section{Funding information}

This research received no specific grant from any funding agency in the public, commercial or not-for-profit sectors.

\section{Data availability statement}

Data sharing is not applicable to this article as no new data were created or analysed in this study.

\section{Disclaimer}

The views and opinions expressed in this article are those of the author and do not necessarily reflect the official policy or position of any affiliated agency of the author.

\section{References}

Baudissen, W.W., 2016, Kyrios als Gottesname im Judentum und Seine Stelle in der Religionsgeschichte: Die Herkunft des Gottesnamens Kyrios in Septuaginta, 2nd edn., De Gruyter, Berlin.

Blumhoffer, C.M., 2016, 'Luke's alteration of Joel 3.1-5 in Acts 2.17-21', New Testament Studies 62(4), 499-516. https://doi.org/10.1017/S0028688516000151

Bousset, W.W., 1970, Kyrios Christos - A history of the belief in Christ from the beginnings of Christianity to Irenaeus, transl. J.E. Steely, Abingdon Press, New York, NY.

Church, P., 2016, 'Hebrews 1:10-12 and the renewal of the cosmos', Tyndale Bulleton 67(2), 269-286.

Collins, J.J., 2012, 'The transformation of the Torah in second temple Judaism', Journal for the Study of Judaism 43(4-5), 455-474. https://doi.org/10.1163/1570063112341235

Collins, J.J., Dever, G.W., McCarter, P.K. \& Redford, D.B., 1997, Aspects of monotheism: How God is one, Biblical Archaeological Society, Washington, DC.

De Troyer, K., 2008, 'The pronunciation of the names of God, with some notes regarding nomina sacra', in I.U. Dalferth \& P. Stoellger (eds.), Gott Nennen: Gottes Namen und Gott als Name, Religion in Philosophy and Theology, vol. 35, pp. 143-172, Mohr Siebeck, Tübingen.

Gericke, J., 2017, What is a God-Philosophical perspectives on divine essence in the Hebrew Bible, Bloomsbury, London.

Gerstenberger, E.S., 2005, 'Israel in der Perserzeit. 5. und 4. Jahrhundert v. Chr', Biblische Enzyklopädie, vol. 8, p. 355, Kohlhammer, Stuttgart.

Gnuse, R.K., 1997, 'No other Gods: Emergent monotheism in Israel', Journal for the study of the Old Testament (Supplement series), 241, 392.

Goodblatt, D., 2006, Elements of ancient Jewish Nationalism, John Knox Press, Westminster.

Grabbe, L.L., 2010, An introduction to second temple Judaism - History and religion of the Jews in the time of Nehemiah, the Maccabees, Hillel and Jesus, T \& T Clark, New York, NY.

Gradel, I., 2002, Emperor worship and Roman Religion, Oxford University Press, Oxford. 
Grenfell, B.P. \& Hunt, A.S. (eds.), 1898, The Oxyrhynchus Papyri, Part I, University of Oxford, London.

Heath, J., 2010, 'Nomina Sacra and Sacra Memoria before the Monastic Age', The Journal of Theological Studies 61(2), 516-549. https://doi.org/10.1093/jts/flq077

Horsley, G.H.R., 1984, New documents illustrating early Christianity - A review of the Greek inscriptions and Papyri Published in 1976, The Ancient History Documentary Research Centre, Macquarie University, Sydney.

Hurtado, L.W., 2003, ' $\mathfrak{P \Re} \mathfrak{P}^{52}$ (P.Rylands Gk. 457) and the Nomina Sacra: Method and probability,' Tyndale Bulletin 54(1), 1-14.

Hurtado, L.W., 2006, The earliest Christian artefacts: Manuscripts and Christian origins, Eerdmans, Grand Rapids, MI.

Israel Museum, n.d., The Digital Dead See Scrolls, viewed 31 March 2020, from http:// dss.collections.imj.org.il/.

Johnson, L.T., 2010, The writings of the New Testament, 3rd edn., Fortress Press, Minneapolis, MN.

Jonker, L.C., 2016, Defining all-Israel in chronicles, FAT, 106, Mohr Siebeck, Tübingen.

Kotansky, R., 1980, 'Two amulets in the Getty Museum: A gold Amulet for Aurelia's epilepsy: An inscribed magical-stone for fever "chills," and headache', The Journal of Paul Getty Museum Journal 8, 180-184.

Llewellyn, S.R., 2002, New documents illustrating early Christianity - A review of the Greek inscriptions and Papyri Published in 1986-1987, vol. 9, Eerdmans, Grand Rapids, MI.

Lynch, M.J., 2014a, Monotheism and institutions in the book of chronicles, FAT II, 64, Mohr Siebeck, Tübingen.

Lynch, M.J., 2014b, 'Mapping monotheism: Modes of monotheistic rhetoric in the Hebrew Bible,' Vetus Testamentum 64(1), 47-68. https://doi.org/10.1163/ 15685330-12341141

Nagel, P., 2012, 'The $\theta \varepsilon$ ó and kúploc terms in the Isaiah Text and their impact on the New Testament: Some observations,' in J. Cook \& H.-J. Stipp (eds.), Text-critical and hermeneutical studies in the Septuagint, Vetus Testamentum Supplements, vol. 157, pp. 173-191, Brill, Leiden.

Nagel, P., 2017a, '“God” constructs at Kirbet Qumran', in E.G. Dafni (hrsg.), Gottesschau - Gotteserkenntnis: Studien zur Theologie der Septuaginta, bnd. 1, pp. 129-130 Mohr Siebeck, Tübingen.

Nagel, P., 2017b, 'Towards a better first-century CE understanding of the term KYPIO $\Sigma$ Contributions from Philo and Paul', Journal of Early Christian History 7(1), 89-110.

Nagel, P., 2019, 'Problematising the Divinity of Jesus: Why Jesus Is Not $\theta \varepsilon o ́$ ', Neotestamentica 53(3), 557-584.

Pfeiffer, S., 2012, 'The imperial cult in Egypt,' in C. Riggs (ed.), The Oxford handbook of Roman Egypt, pp. 139-141, Oxford University Press, Oxford.

Rösel, M., 2000, Adonaj: Warum Gott 'Herr' genannt wird, FAT 29, Mohr Siebeck, Tübingen.

Rösel, M., 2007, 'The reading and translation of the divine name in the Masoretic tradition and the Greek Pentateuch', Journal for the Study of the Old Testament 31(4), 411-428. https://doi.org/10.1177/0309089207080558

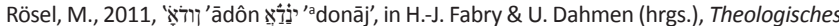
Wörterbuch zu den Qumrantexten, bnd. 1, p. 38, Kohlhammer, Stuttgart.

Shaw, F.E., 2014, The earliest non-mystical Jewish use of l $\alpha \omega$, Peeters, Leuven.

Shechter, J., 2018, The idea of monotheism - The evolution of a foundational concept Hamilton Books, New York, NY.

Sommer, B.D., 2009, The bodies of God and the world of ancient Israel, Cambridge University Press, Cambridge.

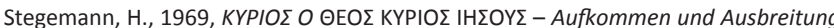
des religiösen Gebrauchs von KURIOS und seine Verwendung im Neuen Testament, Habilitationschrift, Bonn.

Steyn, G.J., 2009, 'Notes on Ps 101 (LXX) and Ps 103 (LXX) in Hebrews 1 in the light of evidence from the Dead Sea Scrolls and Papyrus Bodmer XXIV', Acta Patristica et Byzantina 20, 341-359.

Steyn, G.J., 2010, A quest for the assumed LXX Vorlage of the explicit quotations in Hebrews (Forschungen zur Religion und Literatur des Alten und Neuen Testaments), bnd. 235, Vandenhoeck \& Ruprecht, Göttingen.

The Center for the Study of New Testament Manuscripts, n.d., P46I, viewed 31 March 2020, from http://www.csntm.org/manuscript/View/GA_P46.

The Leon Levy Dead Sea Scrolls Digital Library, n.d., Home, viewed 30 March 2020, from https://www.deadseascrolls.org.il/home.

The Digital Dead Sea Scrolls, n.d., 'The Commentary on Habakkuk Scroll', viewed 31 March 2020, from http://dss.collections.imj.org.il/habakkuk.

The Digital Dead Sea Scrolls, n.d., 'The Community Rule', viewed 31 March 2020, from http://dss.collections.imj.org.il/community.

The Digital Dead Sea Scrolls, n.d., 'The Great Isaiah Scroll', viewed 31 March 2020, from http://dss.collections.imj.org.il/isaiah.

The Digital Dead Sea Scrolls, n.d., 'The Temple Scroll', viewed 31 March 2020, from http://dss.collections.imj.org.il/temple.

Tov, E., 2004, Scribal practices and approaches reflected in the Texts found in the Judean Desert, Brill, Leiden.

Tov, E., 2020, 'Der eine Gott und sein Verständnis Pentateuch,' in H. Ausloos \& B Lemmelijn (eds.), Handbuch zur Septuaginta, Die Theologie der Septuaginta 5/ Handbook of the Septuagint, The Theology of the Septuagint, vol. 5, pp. 47-58, Gütersloher Verlaghaus, Gütersloh.

Trull, G.V., 2004, 'Peter's interpretation of Psalm 16:8-11 in Acts 2:25-32', Bibliotheca Sacra 161, 432-448

Tuckett, C., 2003, “'Nomina Sacra”: Yes and no?', in J.M. Auwers \& H.J. de Jonge (eds.), The Biblical Canons, pp. 431-458, Leuven University Press, Leuven.

Van Bekkum, W.J., 2006, 'What's in the divine name? Exodus 3 in Biblical and Rabbinic tradition', in G.H. van Kooten (ed.), The revelation of the name YHWH to Moses (Perspectives from Judaism, the Pagan Graeco-Roman World, and Early Christianity), pp. 3-15, Brill, Leiden.

Wikipedia, n.d., Papyrus Fouad 266, viewed 31 March 2020, from https://en. wikipedia.org/wiki/Papyrus_Fouad_266. 